\title{
THE REIFICATION OF FATE IN EARLY CHINA
}

\author{
Mercedes Valmisa*
}

\begin{abstract}
Early Chinese texts make us witnesses to debates about the power, or lack thereof, that humans had over the course of events, the outcomes of their actions, and their own lives. In the midst of these discourses on the limits of the efficacy of human agency, the notion of ming 命 took a central position.

In this article, I present a common pattern of thinking about the relationship between the person and the world in early China. I call it the reifying pattern because it consisted in thinking about ming as a hypostasized entity with object-like features. Although external and independent, ming was not endowed with human qualities such as the capacities for empathy, responsivity, and intersubjectivity. The reification of fate implied an understanding of ming as an external, amoral, and determining force that limited humans without accepting intercommunication with them, thereby causing feelings of alienation, powerlessness, and existential incompetence.

I first show that the different meanings of ming hold a sense of prevailing external reality, and hence can be connected to the overarching meaning of fate. Then, I offer an account of the process of reification of fate in early China and its consequences, theoretical and practical, through cases study of received (Mengzi 孟子) and found (Tang Yu zhi dao 唐虞之道) texts. I end with some reflections on the implications of ming as a nonpersonal and nonsubjective type of actor for both early Chinese and twenty-first-century accounts of agency.
\end{abstract}

\section{Overview}

Early Chinese texts make us witnesses to (sometimes implicit) debates about the power, or lack thereof, that humans had over the course of

\footnotetext{
*Mercedes Valmisa, 梅麗, Gettysburg College Philosophy Department; email: mvalmisa@gettysburg.edu

I thank Willard Peterson and Albert Galvany for their insightful comments on earlier versions of this manuscript, all of which helped revise, improve, and add complexity to the presentation of my arguments.
}

(C) The Society for the Study of Early China and Cambridge University Press 2019 
events, the outcomes of their actions, and their own lives. In the midst of these discourses on the limits of the efficacy of human agency, the notion of ming 命 acquired particular relevance and took a central position. In the early Chinese intellectual context, ming encompassed a series of areas of influence over human life, including but not limited to life span, sociopolitical success and failure, times and generation, physical conditions and health, and fortune and misfortune. Overall, we may understand ming as everything that happens without human intervention and remains out of human control. Most early thinkers shared a pattern of thinking about ming that established a problematic relationship between the person and the world: a relationship in which human agents were thought to be overpowered by external, objective, imposing, limiting, and detrimental forces. In early Chinese texts, ming was systematically seen as a problem requiring religious, psychological, or philosophical resolutions.

We find in early China two opposite yet coetaneous patterns of thinking about the relationship between humans and the problematic forces of ming. One of them, which we can call the personifying pattern, personified ming as a deity exclusively in charge of life span: Siming 司命 or the Manager of Allotments (also translated as Director of Allotted Life Spans, Arbiter of Fate, and Master of Fate). ${ }^{1}$ As an anthropomorphized figure, Siming, much like Heaven, the ancestors, and any other deities, was thought capable of intersubjectivity with humans. Humans wrote letters and made offerings and sacrifices to Siming petitioning for someone's life. ${ }^{2}$ As a result, and despite the dubious efficacy of these possibly desperate pleas, people who believed in the figure of Siming must have found therapeutic relief in using the established channels of communication with the god in charge of life. We have evidence for the belief in this deity in charge of life span, Siming, as well as a certain Manager of Misfortunes (Sihuo 司禍), which strongly suggests that there must have existed other religio-bureaucratic positions covering the different aspects of ming mentioned above, to which people could have directed different kinds of petitions. ${ }^{3}$

The second pattern of thinking about the relationship between humans and ming is the object of the present study. I have called it the reifying pattern because it consisted of thinking about ming not as a subject (as it was the case in the personifying pattern), but the opposite: ming was construed as the reified object of fate. The reification of fate implied an understanding of ming as an external, objective, determining

1. See Mark Csikszentmihalyi, "Allotment and Death in Early China," in Mortality in Traditional Chinese Thought, ed. Amy Olberding and Philip J. Ivanhoe (Albany: State University of New York Press, 2011), 178.

2. Csikszentmihalyi, "Allotment and Death in Early China," 179.

3. On Sihou, see also Csikszentmihalyi, "Allotment and Death in Early China," 178. 
reality that confronted and limited the subject without accepting intercommunication with humans. In other words, in the reifying pattern, ming became hypostasized as an external and independent reality, but, short of being a subject, it was not endowed with human qualities such as the capacities for empathy and intersubjectivity.

The personifying and reifying patterns coexisted in tension in early China, which might partially explain the differences between religiopyschological and philosophical approaches to the classical problem on the limits of human agency. While those who believed in the figure of Siming and other managers of fate were offered the opportunity to communicate with these gods through ritual channels in order to petition for the amelioration of their lives, those who viewed ming as impenetrable, amoral, and nonsubjective forces deaf to human pleadings were compelled to develop philosophical responses to deal with the feeling of powerlessness left by those areas of life that escaped human control. ${ }^{4}$

Leaving aside the fascinating topic of the personified managers of destiny, who deserve further studies of their own, this article focuses on analyzing the pattern of thinking about ming as a fate-object, offering an account of the process of reification of fate and its consequences, theoretical and practical, through cases study of the Mengzi 孟子 and the TangYu zhi dao 唐虞之道. I end with some reflections on the implications of ming as a nonsubjective type of actor for both early Chinese and twenty-first-century accounts of agency.

\section{Ming as Fate-Object}

Broadly speaking, everything that is beyond our control is called ming in early China. As the Mengzi defines it, ming is "what happens with no one causing it” (mo zhi zhi er zhi zhe 莫之致而至者). ${ }^{5}$ The Zhuangzi 莊子 gives us another encompassing meaning of ming as "what cannot be avoided" (bu ke nai he 不可奈何). ${ }^{6}$ The Mengzi's definition takes the perspective

4. It is probably no coincidence that most of our philosophical texts mention the figure of Siming only rhetorically while focusing on the vicissitudes proper to a reified

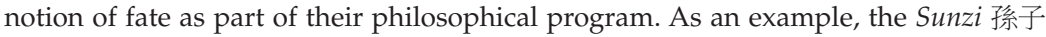
uses the expressions "the people's Manager of Allotments" (min zhi Siming 民之司命, ch. 2) and "the enemy's Manager of Allotments" (di zhi Siming 敵之司命, ch. 6) in a rhetorical effort to convey the fundamental role of a commander in his own people's and the enemy's chances of survival. While here a belief in the figure of Siming is not excluded, neither is it part of the Sunzi's argument.

5. All translations are mine, although I have greatly benefitted from the work of previous translators. Mengzi zhushu 孟子注疏 (Shisan jing zhushu 十三經注疏 ed., 1816; rpt. Taipei: Yiwen, 1985), 6A.169b.

6. Zhuangzi jijie 莊子集解, ed. Wang Xianqian 王先謙 (Beijing: Zhonghua, 1982), 4.38 . 
of the causing agency, whereas the Zhuangzi's evaluates ming from the point of view of its repercussion on humans. All in all, both of them point at the notion that there are events that happen without human intervention and which remain out of human control. These events constitute the phenomenon of ming, an external, objective force that indifferently and persistently affects the subject.

I do not wish to import categories such as fatalism, determinism, and free will from the Western philosophical tradition to frame my discussion of ming, for three reasons. First, those categories do not find one-toone early Chinese counterparts, so they can confuse more than they can clarify. Second, concepts such as fatalism, determinism, and free will are charged with different layers of historically accumulated connotations, and at the same time, perhaps for that very reason, they have become too ambiguous and too empty to be useful at all (as Western philosophers recognize with contempt, like Dennett; with embarrassment, like Searle; or with hope, like Honderich). 7 Third, even if I could temporarily disambiguate the categories for the limited use of this study, engaging with the voluminous Western scholarship in the topics of determinism and free will would be an unnecessarily exhausting task. And here I return to my first reason: Chinese thinkers did not use those categories.

The main category that Chinese thinkers used to talk about a realm of external and amoral forces that exercise determining influence over human life was ming. The reader must be aware that the word ming acquires a variety of different meanings in early Chinese texts: naming, command, mandate, objective circumstances, determining factors, and life span are the most common. ${ }^{8}$ All of these meanings, as diverse as they appear to be, are related in more than one way: philologically, semantically, philosophically, and historically. That is to say, we are dealing

7. See Daniel Dennett, Elbow Room: The Varieties of Free Will Worth Wanting (Cambridge, MA: MIT Press, 1984); John Searle, "Free Will as a Problem in Neurobiology," Philosophy 76 (2001), 491-514; Ted Honderich, On Determinism and Freedom (Edinburgh: Edinburgh University Press, 2005).

8. Fu Sinian 傅斯年 articulated five theories of ming in early China. See Fu, “Xingming gushun bianzheng” 性命古順讋證, in Fu Mengzhen xiansheng ji 傅孟真先生集, vol. 2 (Taipei: Guoli Taiwan daxue, 1952), 114. Nylan, in turn, distinguished twelve meanings of ming in the Han, although many of them can already be seen in the Warring States period, in Michael Nylan, The Canon of Supreme Mystery: A Translation with Commentary of the T'ai Hsüan Qing (Albany: State University of New York Press, 1993), 35. Tang Junyi 唐君毅 associated different attitudes towards ming with Chinese schools of thought, in Tang, “Xian Qin sixiang zhong de tianming guan” 先秦思想中的天命觀, Xinya xuebao 2 (1957), 1-2. For a review of the secondary literature that classifies the different meanings and aspects of ming in early China, see Youngsun Back's dissertation, "Handling Fate: The Ru Discourse on Ming" (University of Wisconsin-Madison, 2013), 8-18. 
with a word, ming, with different yet related meanings (polysemy), and not with different words that coincidentally happen to share graphic or phonetic features but not semantic roots (homonymy). For an exhaustive review of the phenomenon of ming in China, as well as the ramifications and connections between the different meanings of the word ming, I would like to direct the reader to the most comprehensive resource in English: Christopher Lupke's The Magnitude of Ming, a collection of complementary essays by various experts discussing the etymology, semantics, and intellectual history, as well as the sociopolitical, legal, cultural, literary, ritual, and ethical implications of the concept of ming in China from antiquity to the twentieth century. 9

My discussion of ming in this section does not pretend to be exhaustive, as my only goal is to show how different meanings of ming in early texts appear related in one particular way. It is my contention that most of the early Chinese meanings of ming hold a sense of prevailing external objective reality (in both aspects of how we are and what happens to us), and all of them can be gathered behind, or connected to, an overarching meaning of ming as "fate."

The English "fate" comes from the Latin fatum, which literally means "that which has been spoken" and implies a sentence or command of the gods. ${ }^{10}$ In this way, fatum is close to the meaning of tian ming 天命, the command or mandate of god-Heaven, with the only caveat that the early Chinese Heaven does not speak. No text from early China records the words of Heaven, either in direct or indirect style, or suggests that Heaven speaks. In turn, while there is disagreement on the means that Heaven uses to express its will and mandates, testimonies of Heaven's silence and nonverbal means of communication abound. Arguably, most of the philosophical, ethical, and political problems of early China, and the texts that embody these problems, precisely originate from Heaven's silence. The locus classicus for Heaven's wordless nurturing of the world is Analects 17.19, where Confucius compares himself with quiet Heaven in an implicit critique of verbose yet insubstantial and inefficient orators and rhetoricians. ${ }^{11}$ As opposed to the eloquent Greek and Roman gods, the early Chinese Heaven shows its command through the people's actions, the sages' words, and all sorts of natural and cosmic events.

9. Christopher Lupke, ed., The Magnitude of Ming: Command, Allotment, and Fate in Chinese Culture (Honolulu: University of Hawai'i Press, 2005).

10. Jack Newton Lawson, The Concept of Fate in Ancient Mesopotamia of the First Millennium: Toward an Understanding of "Šìmtu" (Wiesbaden: Harrassowitz, 1994), 5.

11. 子曰：天何言哉? 四時行焉, 百物生焉, 天何言哉? (“The Master said: Which use has Heaven for words? The four seasons follow its course, and the hundred kinds of things are born. Which use has Heaven for words?") (Lun yï zhushu 論語注疏 17. 157b). 
Another related sense of fatum (and the Greek moira) is that of one's lot, what is fated to happen, and an allotted life span. ${ }^{12}$ As we will see below, we find a similar meaning of ming in early Chinese texts that points at both descriptive and normative conceptions of life expectancy and life span. Finally, fatum also referred in a more abstract way to an external force that shapes events and influences or determines outcomes. ${ }^{13}$ It is especially in this more general and abstract sense that I translate ming as "fate." That is the overarching meaning of ming that I want to emphasize, as it serves as a connection among all the other particular and concrete meanings. In the following examples, I discuss different meanings of ming in early China as they illustrate the reifying pattern of thinking about ming as a fate-object: an external, objective, determining reality that confronts and limits the subject, thereby introducing a problem that requires a solution.

\section{Ming as Command}

One of the widespread meanings of ming in early texts is command, appointment, and mandate, both as verbs and nouns, and even as a text type. ${ }^{14}$ The reader might be familiar with the notion of tian ming, usually translated as the Mandate of Heaven. The ideology of the Mandate of Heaven, which may have already been in existence by the early Western Zhou period (1046-976 B.C.E.), ${ }^{15}$ granted a personified god-Heaven the capacity to judge human behavior and consequently bestow its mandate to a deserving ruler. This religio-political ideology was used in retrospect to justify conquest and legitimate the victorious ruling house. First applied to the Shang conquest of the Xia, and used repeatedly afterwards, it argued that Heaven shifted its mandate when the virtue of a ruling house decayed, enabling the virtuous conquering power to seemingly effortlessly obtain the throne with the support of Heaven. ${ }^{16}$

12. Lawson, The Concept of Fate, 5 .

13. Lawson, The Concept of Fate, 5.

14. Ming is a textual category in the Documents (Shang shu 尚書), which we can translate as "charges." Other textual categories include "admonitions" (gao 誥), “canons" (dian 典) and "oaths" (shi 誓).

15. Some texts inscribed in early Western Zhou ritual bronze vessels suggest that the ideology of the Mandate of Heaven was already at work in this period. I discuss this issue in the paper "Is the Ideology of the Mandate of Heaven Already Present in Western Zhou Bronze Inscriptions?," presented at the International Consortium for Research in the Humanities (IKGF) in Erlangen, 2018.

16. Sarah Allan has discussed the ideology of the Mandate of Heaven in terms of the tension between the "heir" and the "sage," that is, between hereditary and meritocratic approaches to rulership. See Allan, The Heir and the Sage: Dynastic Legend in Early China (New York: SUNY, 2016). 
However mandated they may have been, Heaven's commands to the king, much as the parallel case of the king's commands to his subordinates, were all tasks to accept voluntarily. That is to say, ming as command or mandate holds no notion of inevitability, yet we may understand a command as being fated in the sense that it belongs to the commanded person by family history, birth, or social and moral condition. ${ }^{17}$ As an example, among the inscriptions that were cast on ritual bronze vessels during the Western Zhou period, some texts are records of investiture ceremonies. They show official subordinates accepting the command, mandate, or appointment $(\operatorname{ming} / \operatorname{ling} \text { 令 })^{18}$ that has been assigned to them by their king, as well as kings accepting Heaven's mandate to rule. ${ }^{19}$ In both cases, the political commands involve legitimate delegation of power within a closed elite circle largely defined by family boundaries. In quite a few inscriptions, the voice of the current king claims to participate in the same power inherited from Heaven as the Former Kings 先王 (Wen 文 and Wu 武), recipients of the original mandate at the beginning of the Zhou dynasty. ${ }^{20}$ By doing so, the current king puts himself in a position to transmit the mandate to his own subordinates, establishing a lineage of power that extends from Heaven to the chosen appointee. Much as the king belongs to a royal lineage that goes back to the Former Kings, the appointed officials belong to a family tradition responsible for serving royal members (as it is apparent in both the Shi Qiang pan 史牆盤 and Lai pan 逨盤 inscriptions). In this sense, they all share a family fate.

17. It is in this sense that Solomon distinguishes between determinism and fatalism. Determinism proposes that there is causal necessity inherent to all events, whereas fatalism offers not a causal necessity but a narrative one. In the fatalist view, outcomes attributed to fate would be necessary only within the narrative of a group that shares a common sense of purpose. Robert C. Solomon, "On Fate and Fatalism," Philosophy East and West 53.4 (2003), 437-39.

18. The terms ming 命 and ling 令 are interchangeable in Western Zhou bronze inscriptions. See Laurent Sagart, The Roots of Old Chinese, Amsterdam Studies in the Theory and History of Linguistic Science 184 (Amsterdam: John Benjamins Publishing Company, 1999) and William Boltz, "Language and Writing," in The Cambridge History of Ancient China: From the Origins of Civilization to 221 B.C, ed. Michael Loewe and Edward Shaughnessy (Cambridge: Cambridge University Press, 1999), 74-91, for a discussion about the intimate relation between these two terms. For the origins of the graph ming and its evolution, see Lin Meiling 林玫玲, Xian Qin zhexue de minglun sixiang 先秦哲學的命論思想 (Taipei: Wenjin, 2007), 54-78.

19. For subordinates accepting appointments, see, for instance, the inscriptions on the Shi Qiang pan 史牆盤 and the Lai pan 逨盤. The royal inscriptions Wu si Hu zhong 五祀㲅 鐘 and Hu gui 㲅篮 are examples of kings accepting Heaven's command to rule as an extension of the original appointment given to the founding kings Wen 文 and $\mathrm{Wu}$ 武.

20. See for instance, Maogong ding 毛公鼎, Da Yu ding and Shi Hong gui. 
The inscriptions present us with two caveats to the notion of ming as an unavoidable and fated command: first, the appointee must be up to the task and accept it; second, it is not a given that, even after having accepted it, the appointee will be able to perform the task. In the bronze texts, these caveats take the form of formal acceptance of the given orders, promises of intentional effective performance, expressions of anxiety in the face of potential failure, as well as pleas for support to the gods and ancestors to be able to fulfill their tasks. ${ }^{21}$ The family fate, is to be understood as an inherited mission in this world rather than as an unavoidable imposition. In some situations, an individual is allotted a particular mission not because of his family relations, but because of his extraordinary virtue. These are exceptional individuals who are chosen to do something great: that is their appointment, lot, or command. The most famous case is probably that of Emperor Yao 堯 abdicating in favor of a worthy man of humble origins, Shun 舜, instead of his own son, a story narrated in the Documents (Canon of Yao and Canon of Shun) but also in found manuscripts such as the Guodian 郭店 bamboo text that editors have called The Way of Tang and Yu (Tang Yu zhi dao 唐虞之道).

In received texts such as the Documents and Odes (Shi jing 詩經), too, it is common to see that the Former Kings' receipt of Heaven's mandate was preceded by demonstration of extraordinary virtue. An illustration of this idea is found in the "Admonishment to Kang" 康誥, where we read that King Wen 可明德慎罰 “was able to be discerning in his virtue and careful in the use of punishments," among other demonstrations of deserving behavior. King Wen's prudence is a precondition for Heaven to offer him the great appointment. ${ }^{22}$ Although this idea is not so common in the bronze inscriptions as it is in received texts, there are a few exceptions, one of which is the Maogong ding 毛公鼎, which reads: 王若曰:父 歆! 丕显文武, 皇天引厌厥德, 配我有周, 膺受大命 (“The King spoke to the effect: 'Father Yin! Wen and Wu, the Greatly Illustrious! August Heaven was greatly content with their charismatic power. They were worthy of our blessed Zhou, and so they received the great appointment.'"' ${ }^{23}$

In all these cases, the appointees endowed with a ming can, but should not, do otherwise. The relationship of this kind of ethico-political command with fate in early China has therefore a soft sense and a strong

21. A greater variety of illustrations of the unstable and compromising nature of the command can be found in received texts. For instance, they abound in the Documents and the Odes. See also Tang Junyi, “The T'ien Ming [Heavenly Ordinance] in Pre-Ch'in China," Philosophy East and West 12.1 (1962), 202.

22. Shang shu zhushu 尚書注疏 (“Kanggao," 201a).

23. Yin Zhou jinwen jicheng shiwen 殷周金文集成釋文 (Hong Kong: Xianggang zhongwen daxue zhongguo wenhua yanjiusuo, 2001), no. 2841. 
one. On one hand, it is a soft kind of fate because it is not completely unavoidable, whether the failure to fulfill the charge is due to choice or malpractice. On the other hand, it is a strong kind of fate because the larger sociopolitical schema demands for the allotted person to follow through with the task to which he has been appointed. Although we do not find in this meaning of ming a fatalistic view of human and heavenly relationships, there are social and moral imperatives to act in a certain way: for the mandated king to govern, and for the appointed official to serve his ruler. In this way, the understanding of ming as command belongs to the more general pattern of thinking of ming as an external imposition of the object of fate. ${ }^{24}$

\section{Ming as Life}

Ming often takes the meaning of life span in early texts. Understood as life expectancy in a descriptive way, it is interchangeable with the term tian nian 天年, the natural number of years that a living being is expected to live according to its species (a tree might be expected to live longer than a person, and a person longer than a cicada). While certainly ming can be a descriptive term signaling the number of years someone lives, it also acquires in early texts a prescriptive connotation pointing at the number of years one is allotted to live. For instance, one Zhuangzi passage in "Great Ancestral Master" (Da zong shi 大宗師) explains that "dying and being born, that is [the works of] ming," in the same way that "the constancy in the succession of days and nights is [the works of] Heaven." ${ }^{25}$ A different Zhuangzi passage in "Metaphorical Language" (Yu yan 寓言) discusses the idea that life and death might both be ordained (ming). One of the speakers of the dialogue challenges the conventional view that life happens spontaneously ( $w u z i$ 無自) whereas death has an external cause (you zi 有自) by setting doubts on what we can actually know about these processes. ${ }^{26}$ Similarly, in the Han philosopher Wang Chong's 王充 words, ming is responsible for "when we are born and die, and whether we are to live long or die early." 27 Our ming in these usages is not describing our life span but pointing at a normative dimension of our allotted years. In the normative sense, our life span would be endowed to us at birth, as a kind of physical individual fate. This ambiguity permeates the early meaning of ming as life in early China.

\footnotetext{
24. See David Schaberg, "Command and the Content of Tradition," in Magnitude of Ming, ed. Lupke, 23-48, for a thorough discussion of ming as command.

25. Zhuangzi jijie 6.58.

26. Zhuangzi jijie 27.248 .

27. Lun heng jiaosh $i$ 論衡校釋, ed. Huang Hui 黃睴 (Beijing: Zhonghua, 1990), 3.20.
} 
However, much as in the meaning of command discussed above, neither ming as life span nor as allotted years necessarily imply inevitability. In several texts, we learn that the person should protect her life and/or allotted living years from being cut off too early. This implies that even in the case of being fated with a pre-determined life span, the amount of years one actually lives may change. For instance, metaphoric trees in the Zhuangzi save themselves from being cut down before their time by being useless to humans. Only those with fine wood will attract the axe..$^{28}$ Another cause of premature death related to the dangers of attracting unnecessary attention, a recurrent theme in the Zhuangzi and other early texts, is punitive execution. A third common cause of dying "early," in this case not involving external intervention, is failing to nurture habits that protect one's health from deteriorating too quickly. Sleeping the adequate number of hours, eating and drinking in moderation, and covering the body with clothes suitable for the season are basic measures everybody can take to live out their years, whether these are simply a matter of life expectancy or a more serious matter of a pre-ordained life span. ${ }^{29}$

We also learn from early texts that, beyond protecting her life span, the person can even choose to try and lengthen it. While some of these strategies to live longer, even to become immortal, are quite feasible and resemble the hygienic habits advised to protect one's life span from being cut off too early, other means are more sophisticated, requiring harmony with the dao 道 and the four seasons, cultivation of inner power ( $d e$ 德), vital energy ( $q i$ 氣) and a complete spirit (quan shen 全神), as well as comprehension of yin yang 陰陽 shifts. $3^{\circ}$ Both scenarios, protecting one's original life span and attempting to extend it, imply that our years of life are susceptible to change.

Yet this understanding of a person's life span is part of the more general view of ming as fate-object in that it works as an externally imposed

\section{Zhuangzi jijie 4.45 .}

29. See, for instance, "Xingshi" 形勢 chapter of the Guanzi 管子. Guanzi jinzhu jinyi 管子今注今譯, ed. Li Mian 李勉 (Taipei: Taiwan shangwu, 1988), 64.940.

30. On these practices, see for instance the Huangdi neijing 黃帝內經. Yang Weijie 楊 維傑, Huangdi neijing suwen yijie 黃帝內經素問譯解 (Taipei: Lequn, 1977), 1.9. Livia Kohn has thoroughly studied Daoist religious and hygienic practices. See, among others, her Introducing Daoism (New York: Routledge, 2008). On the Huangdi neijing and Chinese medicine, see Nathan Sivin, "Huangdi neijing," in Early Chinese Texts: A Bibliographical Guide, ed. Michael Loewe, Early China Special Monograph, no. 2 (Berkeley: Society for the Study of Early China and the Institute of East Asian Studies, University of California, 1993), 196-215; and Paul Unschuld, Huangdi neijing Suwen: Nature, Knowledge, Imagery in an Ancient Chinese Medical Text (Berkeley: University of California Press, 2003). 
pattern of the world that determines how we are and what we are to do. As in the previous case of ming as command, ming as life span holds both a soft and a strong sense of fate. In the soft side, we find that what is given, in this case one's years of life as a human, is not unchangeable and is not beyond human intervention. Whether it is in the descriptive sense of life expectancy or in the normative sense of allotted years, the individual ming can be cut off too early if it is not properly protected and lengthened by resorting to hygienic and alchemic procedures. Yet once again we also find a strong sense of fate in the conception of ming as life. Many early sources contain a critique of those who neglect their years and allow themselves to die before their time. For instance, Zhuangzi's "Robber Zhi" (Dao Zhi 盗跖) chapter harshly criticizes legendary figures such as Bo Yi 伯夷 and Shu Qi 叔齊 who lent themselves to starvation on the margins of the world out of political remonstrance. That they thought themselves to be doing the right thing only proves their commitment to a failed system of beliefs, one that does not have nourishment of long life (yang shou ming 養壽命) at its center. ${ }^{11}$ The Wenzi 文子, in turn, includes in a description of the state of affairs during the Yellow Emperor's (Huangdi 黃帝) golden age the ideal situation that "common people would protect their life spans and not die prematurely." 32 All this suggests that there was a strong current of thought in early China that considered protecting one's life, regardless whether the amount of years is pre-ordained or not, a necessary individual commitment and a moral responsibility.

As in the case of ming as command, our expected or pre-ordained life span is not something that we can determine. It comes to us as a given, posing a problem and requesting a reaction. Ming as life span is not an unavoidable fate, but it is regarded either as a detrimental limit (when it is short and we are encouraged to extend it) or as a responsibility (short or long, we must protect it). In both scenarios, our life span is construed in early Chinese literature as an objective and external imposition, and as a problem that needs addressing and resolution from the subject, which makes it part of the more general understanding of ming as a fate-object.

\section{Ming as Determining Factors}

In Wang Chong's worldview, the duration of our life is just one of the determining aspects of ming. Ming also determines other outcomes, such as whether we are to be rich or poor, fortunate or unfortunate, a

31. Zhuangzi jijie 29.263.

32. Wenzi zuanyi 文子纘義, ed. Du Daojian 杜道堅 (Shanghai: Shanghai guji, 1989), 2.4b. 
success or a failure. It is a complex combination of individual and supraindividual factors which decides the minutiae of one's existence: inborn physical and personal features, social context in which one is located, what one encounters through own efforts, incidents that simply happen, and the general state of affairs of the country-the latter being a transpersonal fate shared by all members of a generation. These competing aspects of ming are hierarchical. The clearest example of the hierarchy found in the Lun heng 論衡 is the transpersonal ming of the state winning over the individual ming (國命勝人命):33 nothing can prevent a strong individual endowed with extraordinary physical features from prematurely dying in war.

With his intricate theory of ming as the combination of determining factors of human life, much as with many of the other writings in the Lun heng, Wang Chong was opposing the common belief of his time (first century C.E.) in a personified god-Heaven that would decree our destinies. ${ }^{34}$ The doings of Heaven, he argued, are not purposeful and do not accord to laws of moral retribution in terms of punishments and rewards for our behavior. Heaven acts in a wuwei 無為 manner: spontaneously and purposelessly. Hence, it is incorrect to blame Heaven for one's outcomes, such as misfortune, and a waste of time to make offerings and issue pleas for Heaven to act on our behalf.

According to Wang Chong, our life is controlled by an interrelated web of competing, determining factors rooted in physical and metaphysical bases. While we can exercise our capacity for purposeful agency in an effort to guide our destinies, the outcomes of our actions and the turn of events are almost never decided by such efforts. It is clear from ordinary experience, the Lun heng argues, that rightful actions do not always help the agent have a successful life. There are simply too many factors playing with our luck for our intentional efforts to be able to exercise enough influence. In most occasions, the different potencies at play in a situation are too strong for our contingent actions to have the power to override them.

Wang Chong's theory of ming offers a clear example of the pattern of thought of ming as fate-object in early China. The different factors that compose ming present an effective, objective, and external determination over the course of the person's life. Much as the conception of ming as command, mandate, or appointment, and ming as life span, the understanding of ming as determining factors assumes a reifying view

33. Lun heng jiaoshi 6.45 .

34. The Lun heng is commonly understood as the work of Wang Chong. However, it is a compilation of many different writings, many of them surely not written by Wang. 
of the different phenomena involved in life and exercising influence on the person where these are conceived in terms of external opposition, determination, and limitation.

We have seen that the different meanings of an impersonal ming were all related to the overarching notion of ming that can be understood as fate: what happens without our intervention, affects us, and cannot/ should not be avoided. We explore the process of reification of fate in early China in detail in the next section.

\section{The Reification of Fate}

Origins of Ming

Scholars of Mesopotamia point to the experience of livelihood in an agrarian society as a likely scenario for the development of the notion of fate. Relying on natural resources such as water, soil, weather, and seasons for sustenance may have made early inhabitants of the world aware that there were forces beyond the divine which, like gods but separate from them, had a determining and inescapable influence over their lives. ${ }^{35}$ In early China, these natural workings and patterns that configure the material, spatial, and natural contexts were subsumed under the categories of Heaven and Earth (tiandi 天地), while fate was, in general terms, rather associated with sociopolitical and individual events. Heaven and Earth were responsible for the cyclical changes of the four seasons; they defined geographical accidents, established cosmic patterns and movements, provided materials means of sustenance, warned through omens, and also threatened (sometimes punished) with floods, earthquakes, and other natural disasters. Fate was in turn responsible for social success and failure, personal physical features and health, life and death, and conditions of living in general. The Confucius of the "Mountain Tree" (Shan mu 山木) chapter of the Zhuangzi, to which we will return, puts it nicely when he associates Heaven and Earth with scarcity of food and water, as well as extreme heat and cold, leaving ming to be responsible for social rank and emolument. ${ }^{36}$

For early Chinese thinkers, the natural order provided by Heaven and Earth could, to a certain extent, be predicted, and even tackled by adjusting to it. A variety of devices such as calendars and other mantic

35. Bernard Clive Dietrich, Death, Fate and the Gods: The Development of a Religious Idea in Greek Popular Belief and in Homer (London: University of London, Athlone Press, 1967), 2.

36. Zhuangzi jijie 20.173. The divide is not always so clear, as tian and ming, Heaven and fate/different kinds of mandates, may appear conflated in philosophical discourses. 
methods were introduced to help humans understand the workings of Heaven and Earth and conform to their natural pattern, thereby putting the natural order to human advantage and preventing it from becoming an impediment to human society's growth, harmony, and stability. As distinguished from the workings of Heaven and Earth, ming was not something that could be predicted, and definitely not something that could be tackled. It belonged, therefore, to a different category of uncontrollable reality, one that was especially problematic.

The understanding of ming as fate-object becomes a pattern of thought in early China that explains human relations to the world as inherently problematic. The fact that there are determining, opposing, reducing, limiting phenomena affecting the control that humans can exercise over their lives is seen as a problem that needs to be addressed and solved. This problem is generally understood in the literature as a tension between nature and humanity, or the problem of the relationship between Heaven and man. For twentieth-century scholars, the different approaches to the dichotomy between Heaven and the human that we find in early texts became a common way to classify positions and isms in early Chinese philosophy, as well as a way to identify developments within the intellectual history of the period. ${ }^{37}$ For instance, A. C. Graham famously spoke of a metaphysical crisis that took place in the fourth century в.C.E.: the intellectual realization of the separation between Heaven and man, and the doubt whether Heaven is after all on the moral side. He then classified Mencius, Zhuangzi, Mozi, and other pre-Qin thinkers according to their approach to the side-effect problem of morality and human nature that had evolved from the split between Heaven and humanity. ${ }^{8}$ In a similar manner, Puett classified philosophers according to the position they take with regard to the relationship between nature and culture, humanity and divinity (a relationship that could be one of continuity and harmony, or discontinuity and tension), tracing the historical development of the different claims and the debates in which these claims were inserted. 39 Whether or not one agrees with the methodological assumptions behind these scholarly efforts to map early Chinese philosophy and intellectual history, they identified and

37. Some of the most important representatives are Tang Junyi, “The T'ien Ming [Heavenly Ordinance] in Pre-Ch'in China," Feng Youlan 馮友蘭, 中國哲學史 (Shanghai: Shangwu, 1934; translated by Derk Bodde as A History of Chinese Philosophy, Princeton, NJ: Princeton University Press, 1983); A. C. Graham, Disputers of the Tao: Philosophical Argument in Ancient China (La Salle, IL: Open Court, 1989); Michael Puett, The Ambivalence of Creation: Debates Concerning Innovation and Artifice in Early China (Stanford, CA: Stanford University Press, 2001).

38. Graham, Disputers of the Tao, 107-8.

39. Puett, The Ambivalence of Creation. 
analyzed important issues in early China, among them the problem of what is beyond human control and the problem of fate. $4^{\circ}$

It is ironic that ming would become such a problematic concept, because, according to scholars such as Chen Ning 陳寧, the notion of a blind, amoral fate was invented in early China as a solution to a previous problem: the problem of theodicy created by the ideology of the Mandate of Heaven. ${ }^{41}$ Simply put, the ideology of the Mandate of Heaven established Heaven as a moral judge of human action. However, in their daily experience, people could see that the virtuous were not always rewarded. Often they even seemed to be penalized. The causal link between moral behavior and success seemed to be broken, which compromised assumptions about the morality and ultimate legitimacy of Heaven. The endangered position of Heaven in this religious conflict is similar to that of the omnipotent Christian god when followers faced the problem of evil. Why would a moral god allow bad things to happen, especially to good people? This problem led in Western traditions to the invention of theodicy: theoretical justifications of a compromised god.

Western theodicy has a long history. The most famous episode in the Western intellectual history of evil is probably that of the earthquake and subsequent tsunami that flooded and destroyed Lisbon and beyond in 1755. The natural disaster triggered a revision of Leibniz's positive theodicy. Leibniz had argued that, in choosing the best of the possible worlds, God had to allow a minimal necessary amount of evil for the greatest good of the community. Evil was therefore a residual illusion only felt from an individualistic and partial point of view. After the catastrophe, which greatly affected the community, Voltaire and Rousseau each issued their critiques of the generally accepted positive theodicy and let the problem of evil off the leash; it would thereafter dominate the intellectual discourse in a reinforced fashion. In early China, the invention of the notion of a blind, amoral fate, an impersonal force of its own unrelated to Heaven, may have been a response to the same problem: blind fate was a power to blame for the existence of evil and injustice, so that Heaven could keep its moral integrity intact. Of course, Heaven, like the Christian god, did not get off so easily. The

40. Common to these twentieth-century approaches (much less so in twenty-first-century scholarship) are the assumptions that (1) masters' texts were authored by the masters that give them name, or disciples within their school of thought; (2) we can date texts and thinkers with enough precision to establish an intellectual line of development within the pre-imperial period.

41. Chen Ning, "The Genesis of the Concept of Blind Fate in Ancient China," Journal of Chinese Religions 25 (1997), 154, 159. Robert Eno, The Confucian Creation of Heaven. Philosophy and the Defense of Ritual Mastery (Albany: State University of New York Press, 1990), 27 . 
human relationship with Heaven became tense and ambiguous, as certain thinkers began to suspect that Heaven was not always moral. We will return to this tension later.

Even if the notion of blind fate started as a solution to a previous problem, it soon became a problem itself. Humans were believed to exist in opposition to an overpowering force that was blind in direction and external in nature, which lashed them arbitrarily and often in detriment of their aims and expectations. For this pattern of thought to become effective, the reification of fate was necessary.

\section{The Process of Reification}

The word "reification" may bring Marxism to the reader's mind. The concept of reification gained currency in Marxist-Hegelian social philosophy in the late nineteenth and early twentieth centuries, especially through Lukács's reinterpretation of Marx's denunciation of the fetishism of commodities in the capitalist system..$^{4^{2}}$ The term originally targeted the "thingification" of social relations. I ask the reader to try and forget about Marx for a minute, and instead grasp the literal meaning of reification as turning a conceptual item into a thing, leaving aside its repercussions and all its implications with regard to Western modernity and capitalism. In the understanding of ming as fate, some early Chinese thinkers turned fate into an object, which was a process that involved different steps and had several important consequences for the intellectual history of the period. The phenomenon known as reification, here understood broadly and adapted to the early Chinese context, provides us with a technical vocabulary that proves appropriate and helpful to theorizing the pattern of thought of ming as fate-object in early China.

In brief, the process of reification of fate, as found in received and excavated early Chinese texts, consists of understanding ming-fate as an external object in opposition to the subject that imposes limits on the subject and is often negative and detrimental to his aims and goals. The following traits of the process of reification of fate in early China can be analyzed separately:

42. Many scholars find the locus classicus of the concept of reification to be György Lukács's History and Class Consciousness, published in 1923. The word "reification" is found and used in different ways in the work of previous philosophers such as Kant, Hegel, Nietzsche, Husserl, and Heidegger to point out the dehumanizing and alienating tendencies of modernity. After Lukács, twentieth-century philosophers have often criticized and reinterpreted the concept in a variety of ways. None of these interpretations is particularly relevant for my usage of the concept here. 


\section{OBJECTIFICATION}

In the reifying pattern of thought, fate is made an object that is opposed to the subject. This is clear not only from the philosophical content of early texts, but also from the use of grammar. The words used to convey the notion of an amoral and blind fate, which are ming and, in some occasions, shi 時 and shi 世 ("the times" and "the age" become objectified as the force of fate) always act as grammatical objects. For instance, as we will see later, it is common to read in these texts that ming is something to be awaited, or something to be accepted. Ming never takes on the role of a subjective agent except when it is personified as Siming. 43 With the exception of the Manager of Allotments, ming never takes on a subjective role in early texts.

The fact that ming never acts as a subject in early China is even more striking when compared with the use of Heaven in early texts. Heaven shares with fate in being a source of explanation for things that happen to humanity. However, and as opposed to fate, Heaven is often anthropomorphized and made a subject. ${ }^{44}$ In early texts, Heaven is portrayed as a full subjective and intentional agent when it makes a command or sends down luck and calamity, when it chooses a new political leader or protects the people from an evil one. Not only does Heaven act, when humans relate to Heaven there are many possible transactions: pleas, prayers, offerings, commands, rewards, punishments, praise, and so on. In the relationship between Heaven and man there is a possibility of intersubjectivity, that is, of exchange, communication, and interpretation of meaning. Humans have the capacity to interact with Heaven.

On the contrary, the reifying pattern rendered ming a blind, deaf, and silent object that had determining influence over human life yet did not accept communication. Of course, as a conceptual entity, fate is different from ordinary objects: it is a hybrid between nature and culture. ${ }^{45}$ Yet in the early Chinese reifying pattern, fate appears reified with object-like

43. On Siming, see the Overview section. In Greek mythology and philosophy, fate also became personified as the "Fates" or Moirae, goddesses with fully intentional and subjective capacity of agency. Lisa Raphals compares the understanding of fate in Greek and early Chinese philosophy in her article "Languages of Fate," in The Magnitude of Ming, ed. Lupke, 70-106.

44. Chen Ning, "The Genesis of the Concept of Blind Fate," 158. Wang Chong is one of the first philosophers to criticize the anthropomorphization of Heaven. In his view, Heaven is not an intentional, subjective agent, but a part of the natural order which acts in a spontaneous, non-purposive manner. We will return to this point in the Implications section.

45. On hybrid objects, see Bruno Latour, We Have Never Been Modern (Cambridge, MA: Harvard University Press, 1993). 
features. One of these features is the lack of subjectivity and responsivity. As opposed to the relationship of humans with gods, which is two-way, transactions are impossible with regard to fate. Humans are passive with regard to fate: they can only accept it, await it, and try to understand it.

Note that "understanding fate" (zhi ming 知命), an important topos in the reifying pattern of thinking to which we will return later, does not involve knowledge of how fate works. Understanding in this context does not imply knowing in a technical way: it is not an attempt to grasp fate's working process, but rather the conviction that fate is beyond human knowledge, and that there is no way to control and overcome it. Understanding fate means to be able to live at peace with fate and to show tolerance toward human ignorance about how it works. It is no surprise that ming often is defined in early texts as 不知所以然而然 者 ("that which happens without knowing the means by which it happens"). ${ }^{6}$ One of the chapters in the Zhuangzi begin by affirming that,

\section{達生之情者, 不務生之所無以為; 達命之情者, 不務知之所無奈何。47}

Those who have mastered the conditions of life do not strive after what life has no means to do. Those who have mastered the conditions of fate do not strive after what knowledge has no means to change.

Not only is fate beyond the reach of our knowledge, but no kind of human knowledge we may have has any effect over the workings of fate and its outcomes. As one anecdote in the Lüshi Chunqiu 呂氏春秋 concerning the figure of Yanzi 晏子, prime minister of the state of Qi 齊 during the Spring and Autumn period and purported author of the Yanzi Chunqiu 晏子春秋, tells us, 人事智巧以舉錯者不得與焉 (“the wisdom and skills used to do and undo human affairs cannot reach [fate]").48 The anecdote qualifies Yanzi as someone who understands fate because he demonstrates accepting that nothing he may know and nothing he may do can get in fate's way. Humans cannot appeal to wisdom or trickery when it comes to fate.

The rupture of any possible relationship between humanity and fate is a consequence of reification. Fate is construed as an opaque object that defies meaning. This opacity turns fate into something dangerous and scary. As hermeneutists know, interpreting (not only texts, but any kind of cultural or natural object) is a way of taming, a way of making

46. See this definition of ming in Zhuangzi jijie 19.163; Lüshi Chunqiu xin jiaoshi 呂氏春 秋新校釋, ed. Chen Qiyou 陳奇猷 (Shanghai: Shanghai guji, 2002 [1984]), 20.8.3, 1347; and Liezi jishi 列子集釋, ed. Yang Bojun 楊伯峻 (Beijing: Zhonghua, 1979), 2.2.64 and 6.6.193.

47. Zhuangzi jijie 19.156.

48. Lüshi Chunqiu xin jiaoshi 20.8.3.1347. 
something manageable, conformable. 49 In their incapacity to interact with fate, humans do not know how to deal with it. The object of fate cannot be interpreted; it renders meaning impossible. Since humanity is affected by fate, the reification of fate not only makes fate meaningless; it also renders the meaning of human life difficult to interpret, even unbearable.

\section{EXTERNALIZATION}

Reification can be defined as "the act (or result of the act) of transforming human properties, relations and actions into properties, relations and actions of man-produced things which have become independent (and which are imagined as originally independent) of man and govern his life." 50 Taken out of its original context, this definition helps us understand the feature of externalization in the reification process in early China. The entity of fate is the subject's cultural creation, but when the creation is reified it becomes externalized and hypostasized, which means that it is given independent and abstract reality external to the subject, as if it had always existed out there, as a fact of nature..$^{1}$

The ascription of the final outcomes of our lives to an external entity that does not depend on our actions or our wisdom, as we have seen in the previous point, is a result of externalization and hypostasis. The feature of externalization is also explicit in the internal-external/subject-object dichotomy (nei 內-wai 外, sometimes expressed in terms of wo 我-wai 外 or $j i$ 己 - wai 外) that many early Chinese thinkers establish. An example of the dichotomy appears in the following lines of the Huainanzi:

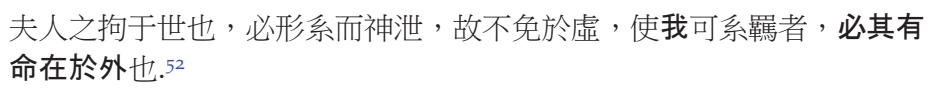

When humans are constrained by their times, their physical form necessarily becomes tied up and their spirit depletes, thus they cannot

49. In her influential 1966 essay, "Against Interpretation," Susan Sontag said that "Real art has the capacity to make us nervous. By reducing the work of art to its content and then interpreting that, one tames the work of art. Interpretation makes art manageable, conformable." Susan Sontag, Against Interpretation and Other Essays (New York: Picador, 1966), 8.

50. Gajo Petrović, "Reification," in A Dictionary of Marxist Thought, ed. Tom Bottomore, Laurence Harris, V. G. Kiernan and Ralph Miliband (Oxford: Blackwell Publishers, 1983), 411 .

51. On this issue see Peter L. Berger and Thomas Luckmann, The Social Constructions of Reality: A Treatise in the Sociology of Knowledge (London: Penguin, 1991; first edition 1967), 106.

52. Huainan honglie jijie 淮南鴻烈集解, comm. Liu Wendian 劉文典 (Beijing: Zhonghua, 1989), 2.10b. 
avert weakness. That $\underline{I}$ can be bound and harnessed is necessarily because there is a fate that lies outside myself.

The "Mountain Tree" chapter in the Zhuangzi gives us another illustration of the feature of externalization, as well as an indication of the opposition between what is considered a result of the works of Heaven and what is a result of fate. In the anecdote, a dignified Confucius 仲尼 explains to his disciple Yan Hui 顏回 that "It is easy to be indifferent to the afflictions of Heaven, but difficult to be indifferent to the benefits of man." 53 Challenging natural situations such as food scarcity and extreme weather conditions are easily understood as the workings of Heaven and Earth, the "afflictions of Heaven," in which humans knowingly play no role. For that reason, it is easy for humans to accept them without major drama. However, when it comes to social success, humans tend to attribute it all to themselves. Confucius argues that, in the same way that natural situations must be attributed to Heaven, satisfying social situations such as attainment of high rank positions and political success must be attributed to fate, not to human effort. However, this is more difficult to acknowledge, as people have a tendency to congratulate themselves for sociopolitical outcomes:

始用四達, 爵祿並至而不窮, 物之所利乃非己也, 吾命有在外者也。54

As soon as one is employed [in office], he succeeds in all four directions. Rank and emolument reach him together and without end. But what is benefiting things is not the self: our fate lies externally to us.

In the next section, I analyze in more detail a case of the "inner-outer" dichotomy in the Mengzi. In the Mengzi, external fate (wai 外) is the realm outside the subject (wo 我) where "seeking does not contribute to achieving," 55 that is to say, where the agent has no control whatsoever. In this and other early texts, fate becomes an externalized object that lies outside human interiority and outside human control. Being externalized and acting as an object in opposition to the subject, fate alienates the subject. The subject becomes separated from the external, objective, and opaque realm of fate, unable to interact with it. Withdrawn into himself, the subject is alienated from its own creation, which brings us to the third point.

53. Zhuangzi jijie 20.173.

54. Zhuangzi jijie 20.173.

55. Mengzi zhushu 7A/3.229b. 


\section{DISENGAGEMENT AND ALIENATION}

When fate is reified, the objective, external realm of fate is experienced as overpowering the subject. It seems like there is nothing the subject can do in the face of fate, apart from passively accepting it and stoically awaiting its charge. At the same time that fate becomes an impenetrable, opaque object that cannot be interpreted or approached, the subject may become alienated from the world and from himself, which brings in disengagement. The belief in the existence of blind fate had manifold implications for human behavior. It left some people feeling powerless and frustrated: what are we supposed to do in the face of an uncontrollable, uncertain destiny? It could also make people careless and lazy in their undertakings: why would I try if everything depends on fate anyway?

Some early Chinese thinkers even considered this conception of fate the root of the main ethical and sociopolitical problems of their times, as it is the case of the Mozi. The thinkers behind the Mozi feared that people would blame everything on fate and would not do anything to ameliorate their lives. They were concerned that if common people took personal failure and success, as well as the country's state of peace and order, or war and chaos, as things beyond their control, they would not find motivation to conduct themselves ethically and to exert efforts to improve their condition. ${ }^{6}$ The belief in a reified, externalized notion of fate would cause a state of ontological slavery: a state of resignation in the face of situations and events that are considered inevitable or, as Nietzsche termed it, a "will to hibernation" without revolt. 57 The idea of hibernation suggests the feelings of disengagement and alienation of the person who experiences reality in this way, those for whom fate is a welcome absolution from the requirement to do anything. ${ }^{8}$

56. See the "Gong Meng" 公孟 chapter. Franklin Perkins notices that the Mohists' major concern when attacking the belief of a preexisting and prescribed fate was to encourage their contemporaries to end war. See Perkins, Heaven and Earth are not Humane: The Problem of Evil in Classical Chinese Philosophy (Bloomington: Indiana University Press, 2014), 56.

57. Nietzsche analyzes different kinds of fatalism, among them the same one criticized by the Mozi, and denounces the "will to hibernation" of those who have placed their fate externally and in opposition to the subject, feeling relieved and content to do nothing in the face of fate. Friedrich Nietzsche, Ecce Homo: How One Becomes What One Is, trans. Duncan Large (Oxford: Oxford University Press, 2007; originally published 1908), 1.6.

58. Peter Sloterdijk, Selected Exaggerations. Conversations and Interviews 1993-2012 (Cambridge: Polity Press, 2016), 302. 
For that reason, the authors of the Mozi would attempt to liberate the person from the slavery of fate by returning all power to the agent and reestablishing a retributory order. We find in the Mozi a world imbued with laws of causality and moral justice, where everyone gets what they cultivate. According to the Mozi, human history and everyday experience give us evidence enough to prove this theory. From history, we can see that virtuous rulers achieved the Mandate of Heaven whereas evil ones lost it. From ordinary experience, we can see that those who care for others are cared for in return, while those who hate are hated. 59 The Mozi emphasizes that humans have power and control over what happens in their lives, and hence they must take responsibility for their own actions and their repercussions, instead of blaming it all on an uncontrollable fate. The authors of the Mozi considered the belief in a reified fate so dangerous that they set up a philosophical program to return all control to the agent.

The implications of the process of reification described above through the features of objectification, externalization, and disengagement made fate a problem, a problem that many early Chinese thinkers were committed to solve. Refuting the existence of fate was the Mozi's denial strategy. Opening an inner realm of moral autonomy for the subject is the proposal we find in texts such as Mengzi and the Guodian 郭店 bamboo texts Tang Yu zhi dao 唐虞之道 and Qiongda yishi 穹達以時. Open-mindedly and adaptively accepting the new situations brought in by fate and taking advantage of them as new possibilities to create a good life was the solution proposed in texts such as the "dead dialogues" of the Zhuangzi. Acting in conformity to the natural order to the extent of dissolving human agency into nature is a strategy that allows for both efficacy and unaccountability in texts such as The Four Classics of the Yellow Emperor (Huangdi sijing 黃帝四經). ${ }^{60}$

The next section provides an illustrated analysis of the reification of fate as it takes place in two early Chinese texts that share the pattern of

59. See, for instance, the third of the "Against fate" 非命 chapters, and the "Inclusive Concern" 兼愛 triad. All the examples argue for a causal connection between actions and success or failure. Perkins' Heaven and Earth are not Humane, 57, includes an interesting discussion on the Mohist argument against a fatalistic notion of fate.

6o. In order to recover existential competence and deal with what seems to be beyond human control, some strategies should be designed. Which solutions did early Chinese thinkers propose to deal with the problem of a reified fate and the uncertainty that it produced? By which means did they recover their existential competence? I discuss some of these solutions in "Beyond our Control? Two Responses to Uncertainty and Fate in Early China," in New Visions of the Zhuangzi, ed. Livia Kohn (St. Petersburg, FL: Three Pines Press, 2015), 1-22. 
thought of ming as a fate-object: the Mengzi 孟子 and the Guodian bamboo manuscript The Way of Tang and Yu.

\section{Two Case Studies of Ming As Fate-Object: Mengzi and Tang Yu zhi Dao}

\section{Mengzi}

In an article that deals with the conception of ming in the Mengzi and the Analects, Ted Slingerland gives the following definition of ming: "forces that lie in the outer realm - that is, the realm beyond the bounds of proper human endeavor, or the area of life in which 'seeking does not contribute to one's getting it."'"61 The spatial description of ming as the outer area in which "seeking does not contribute to one's getting it" comes from Mengzi 7 A.3:

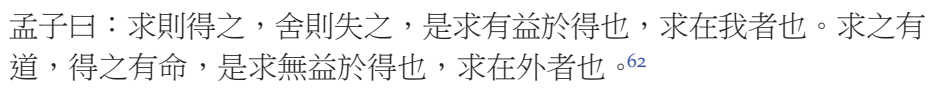

Mengzi said: "When seeking, you obtain them; when neglecting, you lose them. This refers to a case in which seeking helps obtaining, because the seeking lies within oneself. The seeking is proper to the moral way, but the obtaining is nevertheless fated. This refers to a case in which seeking does not help obtaining, because the seeking lies outside oneself."

Slingerland's discussion, which closely follows the Mengzi's classification of phenomena into what is within human control and what is not, interests me because of its emphasis on location. According to the Mengzi, within our control there is the exercise of our inborn virtues. That is the realm of interiority where "seeking helps obtaining." The gentleman (junzi 君子) has the power to examine his interiority (nei xing 內省) and correct his moral behavior accordingly. What makes the gentleman, as well as an ordinary person, a proper human subject is the moral potency that lies within, and over which he can achieve control. In the Mengzi, the four inner virtues constitute the person's subjective interiority: what we really are, or rather, have the potential to become and the power to realize, as distinguished from what comes from outside and remains beyond our control.

61. Edward Slingerland, "The Conception of Ming in Early Confucian Thought," Philosophy East and West 46.4 (1996), 568.

62. Mengzi zhushu $7 \mathrm{~A} / 3.229 \mathrm{~b}$. 


\section{仁義禮智, 非由外鋢我也, 我固有之也.. 故曰：求則得之, 舍則失 之。63}

Humanity, righteousness, ritual propriety, and wisdom are not welded into me from the outside. I have them inherently ... Hence it is said: "When seeking, you obtain them; when neglecting, you lose them."

Opposed to the inner moral realm of the four virtues, which lies within our control, we find the outer, incontrollable, inexplicable realm of ming. The forces that exert influence in our lives belong to the outer realm, a realm that opposes our interiority and quality of subjects. In its identification with an independent and outer realm where human actions do not necessarily lead to the expected outcomes (where "seeking does not contribute to obtaining it" $^{\prime \prime}$, ming becomes objectified and externalized.

In the reifying pattern of thinking, ming is not only reified as an external object that opposes the subject's interiority and sphere of autonomous behavior, but it is also often construed as a negative, opposing object. The identification of the realm of personal interiority with that of morality by means of the four sprouts of virtue (si duan 四端) ${ }^{64}$ allows the external realm to be identified with the amoral. In modern Chinese scholarship, this dichotomy is expressed through the notions of how things are (shiran 實然, or descriptive reality) and how things should be (yingran 應然, or normative reality). ${ }^{65}$ External ming is the vast descriptive realm of how things are; while the internal moral subject is the comparatively smaller but crucial normative realm of how things could and should be. The external realm is not necessarily immoral, but is often perceived as a detrimental limit, not conducive to the development of the normative pursuit of our inborn sprouts of morality.

Ming versus Xing: The Outer and the Inner

In the Mengzi, the tension between descriptive and normative reality, as well as between outer and inner realms, is expressed in terms of a dichotomy between ming (the external, incontrollable realm of fate) and xing 性 (the internal, controllable realm of human nature). The following passages are key to understand the dichotomy between ming and xing,

63. Mengzi zhushu 6A.195a.

64. Mengzi zhushu 2A.66.

65. See, among others, Lao Siguang 勞思光, Xinbian Zhongguo zhexue shi 新編中國哲 學史, vol. I (Taipei: Sanmin, 1984), 197-99. Chen Zhengyang 陳政揚, “Mengzi yu Zhuangzi minglun yanjiu" 孟子與莊子命論研究, Jiedi 8 (2005), 138. 
and how ming is construed in a negative way as an external limitation to the person's moral development and fulfilling life.

孟子曰
口之於味也
目之於色也
耳之於聲也
鼻之於臭也
四肢之於安佚也
性也
有命焉
君子不謂性也
仁之於父子也
義之於君臣也
禮之於賓主也
智之於賢者也
聖人之於天道也
命也
有性焉
君子不謂命也66

Mengzi said:

The mouth's tendency towards [good] flavors, the eye's tendency towards [nice] colors, the ear's tendency towards [pleasant] sounds, the nose's tendency towards [fragrant] odors, the four limbs' tendency towards ease and rest are all innate physical tendencies.

Since fate is involved in [attaining] them, the gentleman does not call them "human nature." The tendency of humanity towards fathers and sons, the tendency of righteousness towards rulers and ministers, the tendency of ritual propriety towards guests and hosts, the tendency of wisdom towards worthies, the tendency of the sage towards the way of Heaven are all [subject to] fate.

Since human nature is involved in [sprouting] them, the gentleman does not call them "fate."

Let us first pay attention to the formal features of these passages. We may understand these passages as a level of commentary inserted within the text. The commentator may be alluding to well-known debates about what must be consider inner and what must be considered outer, such as the one recorded in Mengzi 6A between Mencius and Gaozi 告子. The purpose of the passage is to explain why it is the case that "the gentleman" provides counterintuitive definitions of what belongs to the realm of "human nature" (xing) and what belongs to the realm of "fate" (ming).

The formal features also help us discern the concepts at use. It might be tempting to read the first xing 性 as qing 情 (emotions, conditions, tendencies), given that it stands for sensorial tendencies and motivations such as the eye's attraction towards colors. ${ }^{67}$ However, attention to the parallelism between the last three lines of each section clears the temptation out and forces us to read the word as it appears in the transmitted text: xing 性. The structure of the three last lines in each section has a negative mirroring effect. In each case, we find a distinction between

66. Mengzi zhushu 7 B.253b.

67. Lisa Raphals reads it in this way in "Debates about Fate in Early China," Études Chinoises 33.2 (2014), 27. 
what common sense would tell us that either human nature or fate is, and what the gentleman counterintuitively tells us they actually are. The author of this passage is making a rhetorical point trying to prove that the gentleman has insights that go contrary to what ordinary people think they know. However, the rhetorical point to present the gentleman as a counterintuitive thinker should not prevent us from taking seriously the redefinitions of the concepts of xing and ming that the text presents. The reason for the gentleman's redefinition of the concepts of human nature and fate is also provided in these lines:

[Something seems to be] $X$ because of $Y$ then $\operatorname{not} X$

\section{[Something seems to be] $Y$}

because of $X$

then not $Y$

Sensory desires-what we can translate as "inborn physical tendencies" (the first "xing" in the quoted passage)—belong by common sense or conventional understanding to human nature. They seem to be part of our inner subjectivity, part of our inner self. However, in order to satisfy these impulses, tendencies, and desires-the passage arguesthe senses need to seek outside of themselves, which introduces them into the outer realm of ming, where "seeking does not help obtaining." This is the reason provided by the text to explain why the gentleman does not consider physical tendencies to be part of human nature, or what we could better call "inborn moral tendencies" (the second use of xing). ${ }^{68}$

Ming is present as a potential obstacle to the fulfillment of inborn sensory desires. As we saw before, what conforms the interiority that makes us human subjects is limited to what can be achieved by active seeking: what is within our control. Shifting the meaning of xing from inborn sensory tendencies and desires, common to all humans but also to other animals, to an inner space of moral tendencies specific to humankind, the gentleman is deciding the parameters that define us as exclusively human. In other words, the gentleman is the one qualified to decide what should be considered part of our human inner selves, and what should not. Those inborn tendencies and desires do not belong to the moral interiority that defines humans, not only because their satisfaction

68. The distinction between the two uses of xing has often been noticed. Mou Zongsan 牟宗三, Yuan shan lun 圓善論 (Taipei: Taiwan xuesheng, 1996), 151. Lin Qiping 林啟屏, Cong gudian dao zhengdian: zhongguo gudai ruxue yishi zhi xingcheng 從古典到正 典：中國古代儒學意識之形成（Taipei: Guoli Taiwan daxue，2007)，276. Chen Zhengyang, Mengzi yu Zhuangzi, 137-38. 
lies beyond our control, but also because they do not contribute towards the development of a moral personality. ${ }^{69}$

Let us now look at the other side of the mirroring parallel. Common sense and conventional understanding inform us that activities that involve the practice of virtuous behavior are subjected to different aspects of fate: luck, timing, and appropriate encounters, among others. Even under the right circumstances, it is never certain that a person who practices the virtues will be reciprocated with an equally correct treatment. Therefore, interpersonal ethical behavior should be thought to belong to the realm of what lies outside of our control, the realm of ming. Nevertheless, the gentleman knows that the practice of virtuous conduct is rooted in the inner virtues, which are part of our inviolable interiority. As the quoted passage reads, xing is involved in the sprouting of these virtuous tendencies. That is the reason why the gentleman advises that, despite the fact that the practice of morally correct behavior does not always entail a successful outcome for the virtuous person, these activities must be considered a part of xing in the sense of what makes us specifically human. In qualifying these activities governed by fate as part of human nature, the gentleman is reclaiming them to the inner realm of what is within our control.

In reading ming as an external limitation to our inner selves, I follow scholars such as Mou Zongsan 牟宗三, Lin Qiping 林啟屏, Lao Siguang 勞思光 and Liang Tao 梁濤. $7^{\circ}$ They all offer slightly different interpretations to this Mengzi passage, but generally agree that fate (ming) plays the role of objective reality that limits the fulfillment of the subject (xing) from the outside. There is a clear dichotomy between ming and xing, outside and inside, in this Mengzi passage. The dichotomy works towards creating a counterintuitive understanding of the realms of ming and xing. Where ordinary people would assume that inborn sensory desires and tendencies are inherent to the person and part of our nature (xing), at the same time that interpersonal moral tendencies and ethical behavior are affected by the external operation of fate (ming), the Mengzi's gentleman rectifies these notions. Keeping the spatial image, he gives improved definitions of the realms of personal interiority and the external effects of fate by redesigning their boundaries.

As we saw earlier in the discussion of ming as life span, and as we can see from our discussion of the Mengzi passage, even matters so intuitively

69. See Mou, Yuan shan lun, 151. Xu Fuguan 徐復觀, Zhongguo renxinglun shi-Xian Qin pian 中國人性論史一先秦篇 (Taipei: Taiwan shangwu, 1999), 167-68.

70. See Mou, Yuan shan lun, 151. Lin, Cong gudian dao zhengdian, 276. Lao, Xinbian Zhongguo zhexue shi, 197-99. Liang Tao 梁濤, Guodian zhujian yu Si Meng xuepai 郭店竹 簡與思孟學派 (Beijing: Zhongguo renmin daxue, 2008), 454-55. 
close to our individuality and that we usually construct as intimate, such as our life span, our desires, tendencies, temperament, character, and disposition, once they became attributed to ming, were reified and construed as external limitations imposed on the subject from the outside. What is the subject then? The subject is reduced to the part of us that can make moral choices and has the power to control those choices: our moral inner self. We can decide how to think, act, and react in situations with a moral component, and we have the power to cultivate our virtue. This is the world of human interiority that was created against an external world of confronting, limiting, and hostile reality. ${ }^{71}$ But what exactly constitutes this world of limiting reality, the world of ming?

\section{Ming versus Heaven: Two Kinds of Agency}

From the analysis of the dichotomy between xing and ming we have learned that the Mengzi construed ming as an amoral, detrimental object. In the following, and in order to better understand what is ming, we will direct our attention to the similarities and differences that we find between tian and ming, Heaven and fate, in the Mengzi. Let us begin by reviewing the literature.

According to Chen Ning, the forces of ming in the Mengzi include both Heaven's decisions, which are always moral, and a sort of blind, amoral fate..$^{72}$ When ming is Heaven's moral commands, it resonates with our own moral interiority (our human nature), and we take on them with pleasure. When, on the contrary, the ming we face is the lashes of a blind and amoral destiny, we rather withdraw to ourselves and find autonomy in our moral behavior. In both cases, the person cannot but accept ming. Tang Junyi 唐君毅 and Lin Meiling 林玫玲 have proposed similar arguments. In their view, apart from an undeniable sense of ming as external limitation to our power, there is in the Mengzi a distinct meaning of ming as moral command coming from Heaven. Being in consonance with our moral nature, this moral command does not impose a limit but works as a guide for our ethical behavior. ${ }^{73}$ The proponents of this

71. Some scholars have expressed this conflict in the Mengzi in terms of a difference between ming understood as mingxian 命限 (external limitations) and ming understood as $l i$ ming 立命 (the fate that one establishes for oneself by following a moral path). See Chen Zhengyang, Mengzi yu Zhuangzi, 144. We go back to the idea of li ming at the end of this section.

72. Chen Ning, "The Concept of Fate in Mencius," Philosophy East and West 97.4 (1997), 495. And Chen Ning, Zhongguo gudai mingyunguan de xiandai quanshi 中國古代 命運觀的現代詮釋 (Shenyang: Liaoning jiaoyu, 1999), 131-32.

73. Tang Junyi, Zhongguo zhexue lun -daolun pian 中國哲學原論一導論篇 (Taipei: Taiwan xuesheng, 1993), 526-27. Lin Meiling, Xian Qin zhexue de minglun sixiang, 228. 
second meaning of ming in the Mengzi want to reconcile the dichotomy between our inner moral selves (xing) and Heaven's external commands (ming) that we have previously seen.74 When ming involves a moral command coming from Heaven, it finds resonance in our inner morality to the extent that there is no differentiation between what we are morally predisposed to do (xing), and what Heaven requires us to do (ming).

Michael Puett, on the other hand, has argued that there is only one meaning of ming in the Mengzi: Heaven's decisions. Nevertheless, Puett points out, Heaven's decisions need not always be moral. They are often inscrutable and can even be straightforwardly against the moral plan that Heaven itself conceived for humanity in the first place. 75 Puett uses as example Mengzi 2B/13, where a tragic Mencius speaks of the cyclical pattern of sagely rulership conceived by Heaven. Every five hundred years a true king has arisen, and during that time, a person that we could call a sage because of his capacity to bring peace and order to the world has appeared. Mencius complains that it has already been seven hundred years since the first Zhou rulers, and no true king or sage has arisen yet. According to Mencius, he should be the one appointed for this task, yet his projects as royal advisor have all been a failure. This can only be, Mencius complains, because Heaven does not yet wish to bring peace and order to All under Heaven (夫天, 未欲平治天下也). ${ }^{76}$ Puett concludes that the ambiguity in the term ming is not due to it having different meanings, but it is rather a reflection of the ambiguity felt in face of the relationship between the person and Heaven. Heaven created the moral patterns that should govern the person and the world yet, for unknown reasons, it not always worked in favor of those patterns. 77

I would like to propose a different way of looking at the relationship between tian and ming in the Mengzi. On one hand, I agree with

74. Scholars holding the unifying view promote the slogan "xing ming heyi" 性命合一. For evidence that ming, and xing are not in opposition in the Mengzi, we must turn to revelatory passages in texts such as Zhongyong 中庸 and Xing zi ming chu 性自命出. See, for instance, Yao Yanqi 姚彥淇, “Mengzi 'xingming duiyang' zhang yiyun zaitan" 孟子

「性命對揚」章義藴再探, electronic publication at Guoli Gaoxiong Shifan daxue, www. nknu.edu.tw/ jingxue/download/99jingpdf/o11.pdf, 2010, 8. This line of argumentation is based on the assumption that all these texts belong to the same branch of Confucianism coming from Mencius and Zi Sizi 子思子 and share the same philosophical worldview, hence we can use the one in support of the other. A different methodology is used by scholars such as Fu Sinian and, more recently, Chen Zhengyang, who argue for the unifying view based only in textual evidence found in the Mengzi. See Fu Sinian, Fu Mengzhen xiansheng ji, 355-56; and Chen Zhengyang, Mengzi yu Zhuangzi.

75. Michael Puett, "Following the Commands of Heaven: The Notion of ming in Early China," in The Magnitude of Ming, ed. Lupke, 50-53 and 56-57.

76. Mengzi zhushu 2B.85a.

77. Puett, "Following the Commands of Heaven," 59-61. 
Chen, Tang, and Lin that ming sometimes refers to commands of Heaven, and insofar they come from Heaven, these commands are moral. This is the case when the word ming is short for tian ming ("heaven's mandate" when applied to the sage or the king, and "heaven's commands" when applied to everyone else). It is my contention, however, that the meaning of ming when it is short for tian ming must be distinguished from the meaning of ming when it refers to the blind and external force of fate. In the same way that we distinguish the verb ming when it stands for "giving an order" (wang ming 王命/jun ming 君命, Mengzi) or “replying" (fan ming 反命 Mengzi), we need to differentiate between the moral, Heavenly command, and the amoral forces of fate.

On the other hand, I agree with Puett that in the Mengzi Heaven does not always act in the moral or ethical way that it is expected to. However, I must disagree with the idea that there is only one meaning of ming in the Mengzi, which according to Puett would be Heaven's decisions. As pointed out before, ming is a polyvalent word, and it is used in the Mengzi as well as in other early texts with a variety of meanings, which include command, order, reply, life, mandate, and fate. The ambivalence of ming certainly is due to its polysemic character, and to the way in which early authors consciously or unconsciously dealt with its multiplicity of meanings.

In the following I propose to pay attention to several formal and literary aspects of the passages that make reference to Heaven and ming in order to clarify the difference between these two important concepts, as well as to better understand the reification of ming.

In his study of the Mengzi and Confucian ethics, Shun Kwong-loi points out that Heaven, much as ming, is credited with things over which we have no power. $7^{8}$ Heaven in the Mengzi shares with ming in being a source of explanation for what we cannot explain and what lies beyond our control. Both Heaven and ming are a sort of agency that make things happen or not. They are both heteronomous forces, namely external forces that influence the person from the outside and threaten the person's autonomy and self-determination. Nevertheless, and this is the most important point, Heaven is expected to be moral in the Mengzi, while ming is not.

78. Shun, Kwong-loi, Mencius and Early Chinese Thought (Stanford, CA: Stanford University Press, 1997), 77-78. This is certainly the case in the Mengzi. "Liang Hui wang B," for instance, says that a king must do whatever efforts that will ensure his people inherit a better world, but "whether he is able to accomplish it or not, lies with Heaven" (若夫成功, 則天也) (Mengzi zhushu 2B.46). 
We find a multiplicity of expressions that attribute morality to Heaven in the Mengzi. Some of these expressions are indirect. For instance, "Gongsun Chou A" implies that Heaven is a moral entity by claiming that the king who behaves according to the five moral precepts becomes a minister of Heaven (tian $l i$ 天吏). ${ }^{79}$ In turn, "Gongsun Chou B" uses the notion of the minister of Heaven to claim moral authority over war and conquest: only the minister of Heaven can justly smite another kingdom, in the same way that only a chief criminal judge can justly judge people. ${ }^{80}$ Other expressions are more direct. Several chapters directly attribute virtues to Heaven making it be the source of human morality. ${ }^{81}$ Finally, several passages show that Heaven has moral character, that it has agency, and that it responds to people's actions. ${ }^{82}$ In Mengzi $4 \mathrm{~A}$, Heaven is made a retributive and moral agent that gives the throne to the virtuous ones and enables the defeat of those who lack virtue (ideology of the Mandate of Heaven). ${ }^{8} 3$ A correspondence between human behavior and Heaven's actions is expected. For instance, in Mengzi IB we learn that Heaven will surely send down punitive calamities against a king who does not conquer an evil state (不取, 必有天殊). ${ }^{8}$ This behavior can only be expected when Heaven is considered a moral agent that responds to human action according to an ethical standard.

The fact that Heaven is considered a moral agent, and that it is expected to keep to certain ethical standards, implies that, when Heaven does not act by those standards, humans can feel discontent, angry, frustrated, and lost. This is exactly what happens to Mencius in the story that, as shown above, Puett uses to explain that Heaven can be immoral:

\section{孟子去齊。充虞路問曰：夫子若有不豫色然。前日虞聞諸夫子曰：君 子不怨天, 不尤人。}

When Mencius left Qi, on the journey Chong Yu questioned him, saying: "Master, you seem to carry an air of dissatisfaction in your countenance. But formerly I heard you say, "The gentleman does not complain against Heaven, nor blame men'."

79. Mengzi zhushu 2A.65a.

80. Mengzi zhushu 2B.8ob.

81. Mengzi zhushu 2A.66b; 3A.98b; 6A.204b.

82. See, for instance, Mengzi 1B.31-32, 43 a.

83. Mengzi 4 A.124 says that the calamity of a kingdom is not to not be able to protect itself with big walls against enemies, but to be lacking in virtue, because then Heaven will enable its defeat. Along the same lines, Mengzi 5A.168-171 explains that Heaven gave the throne to Shun because, unlike the Shang king, Shun was virtuous.

84. Mengzi 1B.222. 


\section{曰：彼一時，此一時也。五百年必有王者興，其間必有名世者。由周而} 來, 七百有餘歲矣。以其數則過矣, 以其時考之則可矣。夫天, 未欲平 治天下也 ; 如欲平治天下, 當今之世, 舍我其誰也? 吾何為不豫哉 ? ${ }^{85}$

Mencius said: "That was one time, and this is another. ${ }^{86}$ It is a rule that a [sage] king should arise in the course of five hundred years, and that during that time there should be men illustrious in their generation. From the beginning of the Zhou dynasty until now, more than seven hundred years have elapsed. Judging numerically, the date is past. Examining the character of the present time, we should expect the rise of such individuals in it. But Heaven does not yet wish to bring peace and order to All under Heaven. If it wished to bring peace and order to All under Heaven, in today's world who is there besides me [to do it]? How should I be [otherwise than] dissatisfied?" 87

The keywords in this dialogue are $b u$ yu 不豫, which means to feel discontent, dissatisfied, or displeased; and yuan tian 怨天, which is to complain or murmur against Heaven. The structure of the story is very simple: in theory, one should never complain against Heaven. ${ }^{88}$

85. Mengzi zhushu 2B.85a.

86. I follow Mengzi commentators in their interpretation of this line. The persona of Mencius would be contrasting the time when he said the sentence that his disciple Chong Yu attributes to him ("The gentleman does not complain against Heaven, nor blame men"), and the present time in which the conversation takes place, during Mencius' trip to Qi to deal with a chaotic political situation. See Mengzi zhengyi 孟子正義, vol. 1, ed. Jiao Xun 焦循 (Taipei: Zhonghua, 2009), 309. Due to the current situation, Mencius cannot help feeling discontentment. The same happens to the Confucius of the Analects in several occasions. For instance, when his beloved Yan Yuan 顏淵 died, Confucius cried out "Alas! Heaven has abandoned me, Heaven has abandoned me!" (噫天喪予天㖪予) (Lun yü zhushu 11.97a).

87. This is a contended passage, as it is difficult to accept that Mencius could complain against Heaven. I follow Mengzi commentators in their understanding of this last line as an explanation of why Mencius should feel dissatisfied (我所以有不豫, 為此也). The logic is that Mencius will stop feeling dissatisfied when Heaven decides that it is a good time to stop chaos and charges Mencius with achieving this task. See Mengzi zhengyi, vol. 1, 311 .

88. The phrase, 不怨天不尤人 ("not to complain against Heaven or to grudge against men"), also appears in Analects 14.35, where it is attributed to Confucius. Same phrasing in Lun heng jiaoshi 30.457; Shi ji 17 “Kongzi shi jia" 孔子世家; Shuoyuan jinzhu jinyi 說苑今註今譯, ed. Lu Yuanjun 盧元駿 (Taipei: Taiwan shangwu, 1977), 14.475. Zhongyong zhushu 中庸注疏 52.883 b contains the sentence with a variation: 上不怨天, 下不尤人 ("Above, [the gentleman] does not complain against Heaven; below, he does not grudge against men"). Also with a variation, in Xunzi jishi 荀子集釋, ed. Li Disheng 李滌生 (Taipei: Xuesheng, 1979), 4: 59: 自知者不怨人, 知命者 不怨天 ("Those who know themselves do not complain against men, and those who understand fate do not complain against Heaven"). 
However, Mencius qualifies, there are circumstances that allow for the person to feel discontent and complain: when Heaven seems to act against ethical principles.

We find a similar anecdote in Mengzi ${ }_{5} \mathrm{~A}$. It is parallel to the previous dialogue in vocabulary and structure, with the difference that the object of complaint and dissatisfaction is one's parents, instead of Heaven:

萬章問曰：舜往于田，號泣于旻天，何為其號泣也？

Wan Zhang asked Mencius, saying: "When Shun went into the fields, he cried out and wept towards compassionate Heaven. Why did he cry out and weep?"

孟子曰：怨慕也。

Mencius replied: "He was dissatisfied, and full of earnest desire."

萬章曰：父母愛之，喜而不忘；父母惡之，勞而不怨。然則舜怨乎 ? 89

Wan Zhang said: "When his parents love him, a son rejoices and forgets them not. When his parents hate him, though they punish him, he does not complain. Was Shun then complaining against his parents?"

Then Mengzi proceeds to explain to Wan Zhang how it can be the case that Shun could not help but feel sorrow and express his complaints against his parents. Shun exerted himself in all spheres of life, first to cultivate the fields, then to govern the world. Yet Shun's parents did not consider him worthy of love. No matter how correctly Shun behaved and how successful he became in political matters, he could never achieve his parents' acceptance and support. Mengzi explains that a filial son will always need his parents to be in accord with him (shun 順). Despite enjoying the pleasures of beauty, sensuality, riches, and honors (hao se fu gui 好色富貴), as a filial son who feels unappreciated and undeserving of parental love, Shun could not liberate himself from sorrow (jie you 解憂) to the end of his days. $9^{\circ}$

The keywords in this story are yuan mu 怨慕, dissatisfied and full of earnest desire; yuan (fumu) 怨 (父母), to complain or murmur [against parents]; you 憂, sorrow; and min tian 旻天, which we can translate as "compassionate Heaven." ${ }^{91}$ Note that these words express ideas similar

89. Mengzi zhushu 5A.160a.

90. See the rest of the story in Mengzi 5A.160a-161a.

91. Shuo wen jiezi reads: 仁閔覆下, 則稱旻天 (“It covers everything below with humanity and compassion, therefore it is called 'compassionate Heaven'"). Shuo wen

footnote continued on next page 
to those we found in the previous story: they point at a dissatisfied person sorrowed by ethical injustice who complains against the source of his unhappiness. The structure also parallels the dialogue where Mencius complains against Heaven: in theory, one should not complain against one's parents, but there are circumstances that allow it. Notably, the fact that one's parents behave in what seems an unloving way towards their filial son. Both stories showcase people who are frustrated, sad, and angry against an unsympathetic, unfair superior authority that they respect and love, and of whom they would expect an ethical behavior that is missing. The parallel between the two anecdotes becomes even stronger when we realize that early texts often qualify Heaven and Earth as the parents of the ten thousand types of things..$^{2}$ Heaven takes the role of a father in its relationship with humans. The parallelism between Heaven and a father is clear in the two stories. In the first dialogue, Mencius admits he is discontent and frustrated by Heaven's behavior. In the second, Mencius justifies that Shun could be discontent and sorrowed by his parents' behavior. The people need and expect Heaven's moral guidance, acceptance, and support, much as a filial son needs his parent's love and recognition. Note also that the story about Shun's sorrow begins by making reference to his crying out to a compassionate Heaven (min tian 旻天). Contrary to Laozi's famous statement “Heaven and Earth are not humane" (tiandi bu ren 天地不仁), 93 the Heaven of the Mengzi is a moral entity that is expected to display humanity and righteousness in its behavior. 94

Ming-fate, on the contrary, is not expected to display a moral or ethical behavior. Therefore, the human attitude towards ming will be different from the attitude towards Heaven. Fate can also cause all sorts of

jiezi zhu 說文解字注, attributed to Xu Shen 許慎, comm. Duan Yucai 段玉裁 (Shanghai: Shanghai guji, 1988), 8.46.

92. The epithet "Son of Heaven" for the ruling king suggests that Heaven acts as a father for the ruler. Beyond the ruler's kinship with Heaven (symbolic or otherwise), there are numerous textual examples of the representation of Heaven and Earth as father and mother of the people and all entities ( $\min$ 民/ wanwu 萬物). See, among others, Shang shu zhushu 1A.152b; Zhuangzi jijie 6.58; Guanzi jinzhu jinyi 41.703; Huainan honglie jijie 7.1b; and Heguanzi 鶡冠子, ed. Lu Dian 陸佃 (Taipei: Taiwan zhonghua, 1965), 10.80 .

93. Laozi Daode jing zhu jiaoshi 老子道德經注校釋, ed. Lou Yulie 樓宇烈 (Beijing: Zhonghua, 2008), 185 .

94. In his book named after the famous Laozi phrase, "Heaven and Earth are not Humane," Perkins discusses these Mengzi passages to explore the issue of "Heaven's role in the world" (Perkins, Heaven and Earth are not Humane, 122). However, he reaches the opposite conclusion: "Mengzi has come to equate heaven with fate, ming. Heaven simply represents those forces or events in the world that are inexplicable and irresistible" (p. 123; the idea comes up again on p. 127). 
unethical, undeserved, and unfair outcomes, yet there is no point in feeling discontent and anger, and certainly there is no point in complaining. One can be mad at Heaven because Heaven is an intentional, subjective, and moral agency. However, one cannot be mad at ming because fate is an objective and amoral power: fate is reified as an opaque object that, differently from the personified Heaven, does not admit communication, intersubjectivity, or any sort of interpersonal transactions.

The features of the reifying pattern of thought, where fate is reified as an object, are visible in the semantic field that accompanies ming in texts that share this worldview. In the Mengzi, ming is something to await (si ming 俟命), accompany in harmony (pei ming 配命), accept (shun shou 順受), stand on (li ming 立命), understand (zhi ming 知命), or simply have (you ming 有命). 95 All these verbs that accompany ming in the Mengzi confirm that ming is seen as an external object beyond the subject's control and emphasize its inevitability. At the same time, they imply that the subject must show a particular behavior towards this inevitability. As opposed to the attitude one must have towards Heaven, which allows in certain situations for dissatisfaction and complaint, the correct attitude toward ming is one of acceptance and understanding. The emphasis on accepting and understanding also implies that the object in question is not always easy to accept and understand yet we must make the effort. This difference in attitude suggests that the authors of the Mengzi considered the power of Heaven and the power of fate to be two distinct things.

\section{Standing on Ming: A Solution to the Problem of Fate}

The fact that, as opposed to Heaven, which accepts communication (and may even be compassionate), fate is a sort of objective, external, opaque force with which humanity cannot negotiate, introduced a problem in the relationship between the person and the world. As we have seen before in the study of the dichotomy between ming and xing, the Mengzi's gentleman redefined what belongs to the external realm beyond our control and what belongs to the inner realm of what makes us properly human. This redefinition had two practical consequences. First, reintroducing interpersonal ethical behavior within the realm of what is within our control gave the ordinary person motivation to keep acting correctly, disallowing self-defeating and lazy behavior. Even though the consequences of one's actions could not always be foreseen and remained governed by external fate, one could and should be in

95. I only consider the cases where ming means fate. When ming is used as "command" or "order" in the Mengzi, the most common verb is "receive" (shou 受), but this is irrelevant to my analysis. 
control of his own actions and thoughts. At the same time, eliminating inborn sensory desires from the definition of human nature eliminated distractions and helped the person focus on morality as the only thing that matters as a human..$^{6}$

The solution that the Mengzi proposed to the problem of fate was to do what is right regardless of the outcomes. In other words, the person should not worry about the workings of ming but concentrate only on his virtuous behavior. For instance, in Mengzi ${ }_{5} \mathrm{~A} / 8$, Mencius explains that 孔子進以禮, 退以義, 得之不得曰有命 “Confucius advanced according to propriety and retired according to righteousness. Whether he obtained [office] or not, he said, was a matter of fate." 97 The teaching of this passage, as it faces the problem of a reified, opaque, inhumane, incomprehensible object of fate, is that one should always act in a virtuous way (moral behavior is within human control) and stoically accept the outcomes of one's actions whatever they are (the outcomes belong to the realm of fate, what is beyond human control)..$^{8}$

In my view, Confucius' behavior, in the way it is explained by Mencius in the extract above, is an instance of "standing on ming" (li ming 立命), namely relying on one's fate as it comes and whatever it is. See Mencius' statement below:

孟子曰：殀壽不負, 修身以俟之, 所以立命也。99

Mencius said: "Not allowing that either a premature death or a long life causes double-mindedness, and cultivating oneself while awaiting [whatever may happen], this is the way to stand on fate."

I follow commentators and modern scholars in translating er 武 as "double-mindedness," what we could understand as a kind of moral doubt. Not having duplicity means not to hesitate to follow the proper moral way even when facing challenging circumstances. ${ }^{100}$ The person who does not deviate from morality and continues cultivating himself (xiu shen 修身) while awaiting the charges of fate regardless what they

96. Following Ivanhoe and Schwartz, Back has argued that the $R u$ 需 perceived the world in moral terms and separated it into two domains: one morally relevant (where there is a causal connection between moral actions and non-moral outcomes, such as external goods), and one morally irrelevant (where such connection does not exist). According to Back, ming would be the line separating these two domains, a relational concept that expresses the interrelation between humans and Heaven. See Back, "Handling Fate: The Ru Discourse on Ming," 13-14.

97. Mengzi zhushu 5A.8.

98. Shun also remarks this point. Shun, Mencius and Early Chinese Thought, 79.

99. Mengzi zhushu 7 A.228b.

100. Mengzi Zhengyi, vol. 2, 878. Shun, Mencius and Early Chinese Thought, 79-80. 
bring about is said to "stand on ming." I do not follow commentators and most of modern scholars in my understanding of "standing on ming," as they reduce the spectrum of ming to that of tian ming, Heaven's mandate. For instance, Zhu Xi interprets "standing on ming" as cultivating oneself as to complete our heavenly moral endowments and do not harm them through humanly imposed actions (謂全其天之所付, 不以人為害 之). ${ }^{101}$ According to my analysis, Heaven and fate are two different kinds of agency. Heaven imposes on the person its own kind of ming, but ming is not reduced in the Mengzi (or in other early texts) to the workings of Heaven. Shun has proposed that the difference between Heaven and ming is that "the former emphasizes the source of things due not to human effort and the latter the outcome of such things." ${ }^{\prime 02}$ While this is certainly the case in the passages where ming is short for tian ming, in numerous other occasions ming is a force of its own, an independent agency, often responsible for allotting living beings' life span, among other outcomes. When ming is reified as the object of fate, it is a nonsubjective, opaque, unreachable agency, as opposed to Heaven, which is a subjective agency. As we have seen above, the Mengzi introduces a difference in attitude toward Heaven and ming when the latter stands for a reified fate. "Standing on fate" is part of the correct attitude to show toward fate: it is a way of appropriation of one's fate, a way of taking control over one's life by keeping up with the moral path while accepting one's lot without question or regret.

About the Mengzi and the Analects, Slingerland remarks that "the motivation informing these texts is the desire to change people's views of what is and what is not important, to redirect people's energy and efforts from the external realm to the internal realm of self-cultivation." ${ }^{103}$ A second motivation is the psychological function of providing peace to a troubled mind. Since what happens lies beyond our control, and there is nothing we can do about it, it should not trouble us. As long as the person is sure to be acting correctly in a moral way, she can live at peace with anything that happens in her life, no matter how unfair or dramatic it appears to be. This attitude requires continuous self-reflection and self-rectification: a search of the conditions for a worthy life within oneself.

To recapitulate, the Mengzi has given us a clear illustration of the reifying pattern of thinking about the relationship between the person and the world in early China. In this pattern, ming is hypostasized as something independent and external to the subject; it is reified as an object that opposes or thwarts the subject; acting from the exterior, it entails an amoral limit and a threat to human moral interiority; and it is potentially

101. Mengzi Zhengyi, vol. 2, 878 .

102. Shun, Mencius and Early Chinese Thought, 77 .

103. Slingerland, "The Conception of Ming," 576. 
detrimental to the subject, so it requires human reaction and psychological resolution. In the next section, we see the same features of the reification of fate in a different early Chinese text, The Way of Tang and Yu.

\section{Tang Yu zhi Dao}

Once we have extracted the features of the pattern of thought of ming as fate-object, it is easier to see this pattern repeatedly appear in early texts, both received and found. There is a phrasal structure that establishes that “those who understand fate do not feel sorrow" (知命者不憂). ${ }^{104} \mathrm{We}$ see it in the Wenzi, with a parallel in Huainanzi "Quanyan" 詮言:

\section{道者直己而待命。。。福之至非已之所求, 故不伐其功, 禍之來非已之 所生, 故不悔其行。。故通道者不惑, 知命者不憂 0105}

The way consists in straightening oneself and awaiting fate ... The arrival of fortune is not because one has sought it, so do not brag about its achievement. The arrival of misfortune is not because one has created it, so do not regret its course ... Therefore, those who comprehend the way are not confused, and those who understand fate do not worry.

As we have learned from the parallel dialogues in the previous section, one may rightfully feel sorrow in the face of Heaven, but not in the face of fate. What comes from fate is nothing to feel anxious or to complain about, since fate is not an ethical subjective entity. In this regard, the Liezi 列子 offers additional insights:

\section{死生自命也, 貧窮自時也。怨天折者, 不知命者也; 怨貧窮者, 不知時 者也。當死不懼, 在窮不戚, 知命安時也. 106}

Death and life spring from fate; poverty and exhaustion spring from the times. Those who complain about premature death are those who do not understand fate. Those who complain against poverty and exhaustion are those who do not understand the times. Not being afraid of death and not being distressed by hardship, that's understanding fate and being content with the times.

104. Huainan honglie jijie 14: 17b; Wenzi zuanyi 4: 10a. In the form of zhiming buyou 知 命不憂, see Shi ji “Qu Yuan Jia sheng liezhuan” 屈原賈生列傳 in Shi ji, attributed to Sima Qian 司馬遷 (Beijing: Zhonghua, 1959), 2500; and Han shu, “Jia Yi zhuan” 賈誼傳 in Xin jiaoben Han shu jizhu bing fubian erzhong 新校本漢書集注并附編二種, ed. Yang Jialuo 楊家駱 (Taipei: Dingwen, 1976), 2228. In the Xici shang 繫辭上, we find 樂天知 命, 故不優 “rejoices in Heaven and understands fate, therefore has no anxieties." See Zhou yi zhushu 周易注疏 (Xici shang 繫辭上, 147b).

105. Wenzi zuanyi 4: 9b-10a.

106. Liezi jishi 6.6: 212. 
"Understanding fate," the person is free from sorrow and distress toward what is beyond her control, therefore can concentrate efforts and energy in improving her moral behavior. This is probably what the Master in one of the Lun yü's 論語 aphorisms meant by describing the gentleman as free from sorrow and fear:

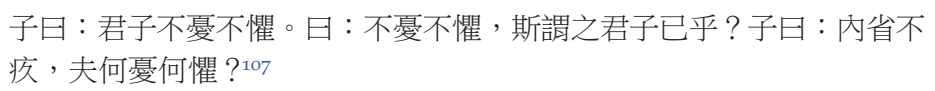

The Master said: "The gentleman has neither anxiety nor fear." [Niu] asked: "No anxiety and no fear, is this what makes a gentleman?" The Master replied: "When inner examination discovers nothing wrong, what is there to be anxious about, what is there to fear?"

"Understanding fate" (zhi ming) is a particularly important topos in the pattern of thought of ming as fate-object. We find this topos in many early texts such as Xunzi, Shuoyuan, Liezi, Wenzi, Huainanzi, and Lüshi Chun$q i u$, to name just a few. The notion of "understanding fate" is normally associated with the reification, externalization, and problematization of fate in early China. I include an example from a manuscript that was found at Guodian in 1993, and which has stirred up much attention.

The Way of Tang and $Y u$ is a relatively short argumentative text that defends abdication and government by merit, as opposed to hereditary monarchy, as the best political option. ${ }^{108}$ What is interesting for me here is how it reflects the reifying pattern of thought of ming as fate-object. In The Way of Tang and $Y u$ we find the same pattern that we have seen in the Mengzi: (1) Dichotomy and relationship of opposition between an inner subject and an external object; (2) Fate presented as a limiting, opposing object; (3) Fate presented as often detrimental to the subject; (4) Therefore, fate presented as a problem.

In the bamboo text, we see a clear differentiation between the inner realm of things that are under the subject's control, such as

107. Lun yü zhushu 12.106b.

108. The manuscript was first published in Guodian Chumu zhujian 郭店楚墓竹簡, ed. Jingmenshi bowuguan 荆門市博物館 (Beijing: Wenwu, 1998), 39-41 and 157-59. For an English analysis of the material features of the manuscript and the intellectual content of The Way of Tang and Yu, see Scott Cook, The Bamboo Texts of Guodian: A Study and Complete Translation (Ithaca, NY: Cornell University Press, 2012), vol. 1, 521-64. Sarah Allan discusses The Way of Tang and $Y u$, together with other manuscripts from the Warring States period, in terms of their strong advocacy for political abdication. According to Allan, other narratives of abdication are found in the transmitted "Yao dian" 藥典 chapter of the Documents, Mengzi 5A "Wan zhang shang" 萬章上, and the "Shang xian" 尚賢 trilogy of the Mozi, as well as in the found texts Rongchengshi 容成氏, Zigao 子羔 and Bao xun 保訓. See Sarah Allan, Buried Ideas: Legends of Abdication and Ideal Government in Early China (Albany: State University of New York Press, 2015). 
self-cultivation in the virtues, and the external realm of ming: the objective, larger world of events that inevitably happen and affect the subject's life. According to The Way of Tang and Yu, the mythical emperor Tang Yao's 唐堯 abdication to Yu Shun 虞舜 was due to numerous factors, which can be divided into two categories. The first category of factors belongs to the inner realm of Shun's virtue: he had been shown to be humane (ren 仁) and sagely (sheng 聖), filial (xiao 孝) and loyal (zhong 忠). Yao knew that these qualities would make him a good ruler for All under Heaven ([知其能]為民主也). ${ }^{109}$ According to the text, Shun achieved these qualities through self-cultivation. They belong to his inner self, the realm that remains within the subject's control under all circumstances. This is indeed the author's key argument in favor of abdication. Sagely government is based on the premise that the person is able to cultivate a correct moral behavior, and only then he will be prepared to bring order to the world. Hence the throne should only pass to the person who has already accomplished such virtuous merit. In the author's words,

必正其身, 然後正世, 聖道備矣 (Guodian 39: 3) $)^{110}$

He must correct his own person and only then correct his generation. ${ }^{111}$

The way of the sage is thus completed.

The second category of factors involved in the making of a legitimate ruler belongs to the external realm, the one that is outside human control. Heaven and Earth, and the world of numinous beings, are forces alien to the subject; they are objective and necessary, not susceptible to be changed by human agency. They all have determining influence over the course of events. All the elements that jointly play the role of fate, namely Heaven and Earth, natural elements such as mountains and rivers, and ancestors and other numinous beings, are treated as spirits or gods that

109. Guodian Chumu zhujian, 158. The addition of the three missing characters in brackets [知其能] is unproblematic, as they are supplied by parallelism with the two previous sentences. See Li Ling 李零, Guodian Chujian jiaoduji 郭店楚簡校讀記 (Beijing: Zhongguo renmin daxue, 2002), 95.

110. I am referring the reader to the pages that show the slips' photographs, and to the number of the slips where the text I am quoting appears.

111. The precondition of rectifying oneself through self-cultivation before attempting to govern the world is a common theme in early Chinese political texts. The locus classicus in the Analects reads: 子曰 : 苟正其身矣, 於從政乎何有? 不能正其身, 如正人何? ("The Master said: If a minister rectifies himself, what difficulty will he have in assisting in government? If he cannot rectify himself, how can he rectify others?") The same theme appears with similar phrasing in parallel passages in Shuoyuan jinzhu jinyi 1.41 and Kongzi jiayu 孔子家語, ed. Wang Yuan 王淵 (Shanghai: Shanghai guji, 1987), 2.15. 
must receive offerings and religious rituals. ${ }^{112}$ Religious rituals have certainly the goal of modifying the gods' interaction with humans, to make them benevolent. Yet they precisely assume that the gods' agency is outside our control, and that it does not necessarily suit our interests. ${ }^{113}$

Together with these numinous forces, or precisely made out of a combination of them, we find the supra-notions of fate and time. In the last paragraph of The Way of Tang and $Y u$, the author argues that, even though Yao was born as Son of Heaven, and he had cultivated the virtues, he would not have gained control of All under Heaven had not it been because of the matching forces of fate and time/opportunity:

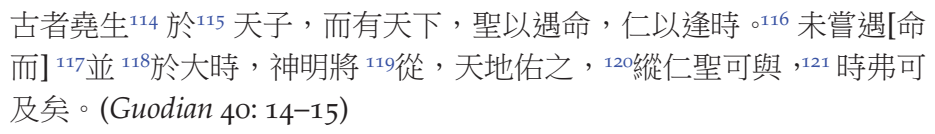

112. Guodian Chumu zhujian, 157.

113. Puett, The Ambivalence of Creation, $27-28$ and 35-36.

114. sheng 生 can be read as "being born" in the royal family with the succeeding king position, as in my translation above, or as sheng 升, to raise as Son of Heaven, much as Shun would raise after Yao despite his plebeian origins. As Cook notes, in the received literature there is more evidence for Yao having received the throne through hereditary succession than by abdication. See Cook, The Bamboo Texts of Guodian, vol. 1, 559, footnote 87. Although it seems open to interpretation in this text, I would suggest that, Tang Yu zhi dao being an open and unapologetic statement in favor of abdication, had the author wanted to claim non-royal origins for Yao, he would have done so more explicitly.

115. Li Ling reads $y u$ 於 as wei 為. Li Ling, Guodian Chujian jiaoduji, 98. Also in Li Ling “Guodian Chujian jiaoduji” 郭店楚簡校讀記, Daojia wenhua yanjiu 17 (1999), 455-56.

116. Zhou Fengwu ends the sentence here, and Cook follows. I agree with this arrangement. See Zhou Fengwu 周鳳五, “Guodian Chumu zhujian 'Tang Yu zhi Dao' xinshi" 郭店楚墓竹簡唐虞之道新釋, Zhongyang yanjiuyuan lishi yuyan yanjiusuo jikan 70.3 (1999), 739-59; and Cook, The Bamboo Texts of Guodian, vol. 1, 559, footnote 90.

117. Missing characters. Li Ling supplies them with xian 賢 and sui 雖. Li Ling, Guodian Chujian jiaoduji, 98. I follow Zhou Fengwu, "Guodian Chumu zhujian 'Tang Yu zhi Dao' xinshi," and Cook, The Bamboo Texts of Guodian, in the choice of characters, but not in their reading.

118. I follow Li Ling, Guodian Chujian jiaoduji, 98, in reading bing 並as bing 秉, to grasp.

119. The editors rendered this graph as jun 均: "all," "equally." Even though the change in meaning is not decisive, I follow Li Ling, Guodian Chujian jiaodjui, 98, in reading jiang 將.

120. Li Ling punctuates with a comma where other editors have seen a full stop. I follow Li Ling, Guodian Chujian jiaoduji, 98, and Chen Wei 陳偉, Guodian zhushu bieshi 郭店竹書別釋 (Wuhan: Hubei jiaoyu, 2012) to see the entire sentence as a hypothetical conditional: "had he not yet" (wei chang 未嘗), “then, even though" (cong 縱). For a summary of other arrangements and word choices, see Cook, The Bamboo Texts of Guodian, vol. 1, 559 and Allan, Buried Ideas, 130.

121. I follow Li Ling, Guodian Chujian jiaoduji, 98 , in reading yu 與 as $j u$ 舉, to elevate. 
In antiquity, Yao was born as the Son of Heaven, but the reason why he was in control of All under Heaven was that his sagely virtue encountered [favorable] fate, and his humanity met with [appropriate] times. Had he not yet encountered his fate and grasped the great opportunity, [with the result that] everything numinous and luminous would follow, [and that] Heaven and Earth would assist him, [then] even though his humanity and sagacity were worthy of elevation, the right time could not have been made to arrive.

Similar arguments can be seen in the Qiongda yishi 笨達以時, also a bamboo text from Guodian, which argued that historical figures such as Shun and Guan Zhong 管仲 were only able to succeed by virtue of timely and fated encounters. ${ }^{122}$ Ming is that external and objective reality that one encounters ( $y u$ 遇), for good or bad. Often it only frustrates the subject's aspirations. Nevertheless, when the course of fate matches the moral qualities of a person, we can expect great outcomes.

But, even though it escapes our control and can act in detriment to our goals, according to Tang Yu zhi dao, ming should become an object of our accepting understanding. The bamboo manuscript contains the phrase zhi ming, understanding fate, in the following context:

\section{夫古者舜居於草茅之中而不憂，登 123 為天子而不驕。居草茅之中而不 憂, 知命也。登為天子而不驕, 不專 ${ }^{124}$ 也。(Guodian 40: 16-17)}

In antiquity, Shun lived in the countryside ${ }^{125}$ and this did not make him afflicted. When he became the Son of Heaven, this did not make

122. See Valmisa, "Beyond our Control?"

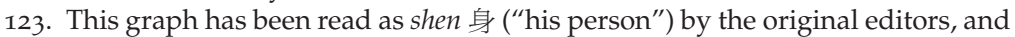
as sheng 升, ("to elevate") by Qiu Xigui and others. I follow Li Ling, Guodian Chujian jiaoduji, 98, in reading deng 登, with the similar meaning of "climbing up," "rising." All choices point at the same reading.

124. I follow Li Ling's reading of this graph as zhuan 專, "especial," "unique." Another possible reading is liu 流, in the sense of "to give oneself to abandon." See Cook, The Bamboo Texts of Gudodian, vol. 1, 560. I understand bu zhuan 不專 in the same sense given in other early texts of not acting arbitrarily and tyrannically according to one's own wishes. See, for instance, Wenzi 4: 5b (不為始, 不專已), and Qian fu lun jian jiaozheng 潛夫論箋校正, attributed to Wang Fu 王符, ed. Peng Duo 彭鐸 (Taipei: Zhonghua, 1985), 6.25.293 (不專任以斷事). If we read the graph as zhuan 專, it can also be understood in the sense of "monopolizing" (the throne, or its benefits; see Allan, Buried Ideas, 93-95) within a family lineage. Namely, the opposite of abdication, as in the opening sentence of the manuscript: 唐虞之道, 禪而不專 (“The way of Tang and Yu was to abdicate and not to monopolize") (Li Ling, Guodian Chujian jiaoduji, 95).

125. Other texts, such as the manuscript from the Shanghai Museum Collection Zigao 子羔, and the Zhanguo ce 戰國策, coincide in that Yao found Shun in the middle 
him arrogant. ${ }^{126}$ Living in the countryside without feeling affliction is to understand fate. Becoming the Son of Heaven without turning arrogant is not to feel special.

The precedent that Shun set became a teaching for the contemporaneous generation of politicians:

\section{方在下位, 不以匹夫為輕 ; 及其有天下也, 不以天下為重。有天下弗能 益, 無天下弗能損。(Guodian 40: 18-19)}

When placed in a low position, they must not consider the ordinary person unimportant. And when in possession of All under Heaven, they must not consider [the possession of] All under Heaven as the most important. Possessing All under Heaven does not add anything. Not possessing All under Heaven does not decrease anything.

The author of the Tang $Y u$ zhi dao encourages his contemporary politicians to "understand fate" the way Shun did. Even when Shun lived in a low position in the middle of nowhere, the author observes, he had no thirst to become powerful and important. As Sarah Allan notes, "the statement that Shun did not feel resentful even though he lived in a thatched hut [what I have translated as the "countryside"] implies that before Yao raised him up, he was a man of worth waiting for recognition rather than a simple farmer." 127 Allan interprets Shun's behavior as virtuous. He would be "the epitome of humility." 128 In my understanding, Shun knew that sociopolitical rise was outside of his control, no matter how cultivated and well prepared he could be to be of service to the realm. His lack of emotional response in the face of

of the countryside, that is, far away from the court. See Cook, The Bamboo Texts of Guodian, vol. 1, 560, footnote 102 .

126. The idea of rising to a high position or being morally superior without showing pride is a common theme in early texts. For superiority in terms of moral character, see the Analects, which contrasts the superior and inferior person in this way: 君子泰而 不驕, 小人驕而不泰 (“The gentleman is poised and not arrogant; the base person is arrogant and not poised") (Lun yü zhushu 13.119b). For superiority in terms of position, see Zhong yong describing the gentleman: 是故居上不驕, 為下不倍 (“Thus, when occupying a high position he is not arrogant, and in a low position he is not insubordinate") (Zhong yong zhushu 31.898a). A closer contrast to the one that appears in Tang Yu zhi dao is found in Lüshi chunqiu 1.2.21: 上為天子而不驕, 下為匹夫而不惛 (“Acting above as the Son of Heaven he is not arrogant; acting below as a common man he is not depressed").

127. Allan, Buried Ideas, 109.

128. Allan, Buried Ideas, 109. 
the unresponsiveness of the world to his moral cultivation shows his realism. It shows that Shun understands ming. ${ }^{129}$

Of course, understanding ming is a characteristic of the virtuous person and a precondition to become a gentleman, because the fact that one understands ming has the implication that the external world of fate cannot impose any limits on one's inner moral development. ${ }^{130}$ Shun would not wish for anything to change; he had no aspirations or desires for his life to become different. He would not show ambition, resentment, or regret. Understanding fate has, then, two sides. On one hand, while self-cultivation is in our power and control, the subject has no say on what will happen as a consequence of his moral behavior, because this outcome belongs to the external realm of fate. From this perspective, fate can act as a detrimental limit to human agency, and becomes problematic. On the other hand, when one understands the workings of fate and accepts them, fate cannot do anything against the subject's mind, against his interiority. The subject's moral autonomy remains intact as an untouchable and invulnerable inner realm. This is one of the proposed solutions to the problem of the reification of fate in early China.

\section{Implications}

We have seen that the reifying pattern of thinking about the relationship between the person and the world construes fate as a hypostasized entity with object-like features. Yet in early China fate is an object that acts. How can this be the case? Can objects be agents? When we think about agency, we normally think about subjective, human agency. In the standard theory, agency is the capacity to select intentional, goaldirected actions. The agent's mental states and processes cause the intentionality of action that will lead to actually acting. ${ }^{131}$ Our conception of agency, insofar it regards distinctively human agency, is permeated with qualities such as intentionality, purpose, volition, reflectivity, empathy,

129. A reader interested in literary and philosophical comparisons will like to know that there are similar lines of argument in the Western tradition. Famously, Petrarch's Remedies Against Fortuna reinterpreted the Stoic standpoint towards fate and created a therapeutic manual to learn to cope with Fortuna's capricious lashes. The advice was to develop indifference and distance: to learn to care as little for lucky outcomes as for disastrous ones.

130. On "understanding ming" as a precondition to becoming a gentleman, see the Analects: 不知命, 無以為君子也 ("If one does not understand ming, one does not have the means to become a gentleman") (Lun yü zhushu 20.180a).

131. On the standard conception and theory of agency, see Markus Schlosser, "Agency," The Stanford Encyclopedia of Philosophy, Fall 2015 edition, ed. Edward N. Zalta, https:/ / plato.stanford.edu/archives/fall2015/entries/agency/. 
and meaning, all of them qualities that, in principle, cannot be ascribed to non-thinking, unconscious objects.

Many have been the critics of the standard theory of agency, which, it has been repeatedly argued, fails to capture the phenomenon of agency in all of its complexity. In particular, the critics have questioned the necessity of the notions of intentionality and causation when we discuss agency, as it seems that entities without intentional capacity can also perform actions. Within this line of thought, sociologist Bruno Latour has redefined agency to account for non-human and non-subjective agents. If we were to suspend the qualities that we associate with humanity and subjectivity, and to reduce agency to its minimal notion, we would find that anything that "modifies a state of affairs by making a difference" is an agent. ${ }^{132}$ In his analysis, a minimal notion of agency allows for a wider understanding of what may count as an agent, a participant in the course of action.

As a sophisticated identification test, Latour has devised some hermeneutical keys to decipher when we may be dealing with an agent in oral or written accounts. I have found it an illuminating exercise to reflect on how these tests apply to the early Chinese notion of ming. First of all, Latour points out, agencies are always presented in accounts as doing something. An agency must make a difference in the course of some other agent's action; it must produce an effect, a change in the state of affairs. Something that does not produce transformation and makes no difference is not an agency. ${ }^{133}$ In early Chinese accounts, ming when understood as fate-object is always presented as doing things, making things happen as well as preventing things from happening. Ming has a concrete and visible effect on the lives of humans, which according to Latour's foremost and most fundamental test would qualify it as an agent.

Second, agencies must have figurations; namely, they must appear fleshed out in accounts, identified with something no matter how vague this identification may be. Contrary to his fellow social scientists, Latour insists that there are many more figures to illustrate agency than anthropomorphic ones. Also, the same agency might be illustrated and discussed using a variety of different kinds of figurations. ${ }^{134}$ Throughout this article we have seen a diversity of accounts of non-human agency figurations, concretely in the forms of the times, the generation, an opportunity, and a somewhat vaguer but overarching supra-entity

132. Bruno Latour, Reassembling the Social: An Introduction to Actor-Network-Theory (Oxford: Oxford University Press, 2005), 71.

133. Latour, Reassembling the Social, 52-53.

134. Latour, Reassembling the Social, 54. When actors have more than one figuration, or no explicit figuration yet, Latour calls them "actants." 
named fate. These would be but different figurations to represent the same agent (or "actant" in Latour's vocabulary). ${ }^{135}$

At the same time, Latour continues, accounts of agency are likely to withdraw other possible agencies as illegitimate. ${ }^{136}$ We often see this phenomenon in early Chinese texts, with structures in the form of 非 $x$ 也, $\mathrm{y}$ 也 (it is not due to $\mathrm{x}$, it is due to y), or 皆 $\mathrm{x}$ 也, 非 $\mathrm{y}$ (it is all due to $x$, not to $y$ ). These structures most often oppose the agencies of Heaven and the human, or that of fate and the human. For instance, one of the chapters of the Zhuangzi attributes the "ten thousand types of evil" to the agency of Heaven, withdrawing the possibility that those evils could come from humanity: 若是而萬惡至者, 皆天也, 而非人也 (“If this is so yet the ten thousand types of evil arrive, it is all due to Heaven, not to men"). ${ }^{137}$ Contrasting what lies with humans and what lies with fate, the Liezi explains that 然而生生死死, 非物非我, 皆命也 (“All of the lives and deaths do not lie with other entities and do not lie with myself: they all depend on fate"). ${ }^{138}$ The opposite case is found in the Shuo yuan, where Confucius identifies three kinds of death that are self-inflicted, and cannot be attributed to fate: 此三者, 非命也, 人自取之 (“These three (kinds of death) are not due to fate; people take hold of them themselves") ${ }^{139}$ All these examples show Heaven and fate represented as agents in accounts that identify a source of agency by means of withdrawing the possibility of a different source of agency's responsibility for a certain outcome or event.

Finally, according to Latour, agencies have their own accounts of the theory of action where they fit, as a meta-theory about how agency acts. These theories of action explain how the agency is supposed to act, how it makes things happen or prevents things from happening; in short, how it makes its influence felt. ${ }^{140}$ For instance, one may ask whether the agent acts directly or, on the contrary, whether it has a mediator. There are different ways in which we can understand non-human and non-subjective agency in early Chinese philosophy. If we can agree that fate is construed as an object in the early Chinese reifying pattern of thinking, and that at the same time it is presented as an agent, it is then time to ask how fate is portrayed to act.

135. The early Chinese loose identifications of a hybrid and obscure agency behind certain actions, events, or behaviors, as in " $x$ is due to fate," should remind us of today's equally loose ascriptions of actions, events, and behaviors to similarly hybrid and obscure entities such as "culture," as in "she did x because it is her culture."

136. Latour, Reassembling the Social, 56.

137. Zhuangzi jijie 23.201.

138. Liezi jishi 6.6.203.

139. Shuo yuan jinzhu jinyi $17.7 \mathrm{~b}-8 \mathrm{a}$.

140. Latour, Reassembling the Social, 58. 
Early Chinese accounts of the agency of fate fail to provide a definite theory of action. Even more, many of these accounts openly claim the impossibility of knowing how fate acts, with the result that we find ourselves at a loss when attempting to identify a theory of action behind fate's non-subjective agency. In this situation, a comparison with the way in which Heaven is portrayed to act in early texts is in order. As opposed to fate, Heaven is portrayed exercising its agency in a variety of ways. First of all, Heaven, when an intentional, subjective, and anthropomorphized force, takes direct action when it supports a virtuous leader or when it sends down warnings and calamities in the form of natural phenomena. In the Mozi we learn that, as a reward to the ancient sages' efforts to understand Heaven's will (tian zhi 天志) and to act according to it,

天之為寒熱也節, 四時調, 陰陽雨露也時, 五穀孰, 六畜遂, 疾災戻疫 凶饑則不至。141

Heaven made heat and cold temperature be well adjusted, the four seasons harmonious, the yin yang and rain and dew, [Heaven] made timely. [As a consequence], the five [kinds of] grains could ripen, and the six [kinds of] domestic animals could mature. Disease, disasters, crime, pestilence, inauspiciousness, and famine did not arrive.

That is to say, Heaven is portrayed causing things to happen through its own power. ${ }^{142}$ But Heaven can also act through other means. In modern social sciences there are different theories of social agentivity that aim to explain how social and nonphysical entities such as corporations and economic structures can take action, not directly but through the use of human representatives. ${ }^{143}$ Although social and collective objects are not supposed to be able to act in physical ways, they can take action through physical agents, such as the people who work and lead the corporations. In early Chinese texts, Heaven is also sometimes

141. Mozi xiangu 墨子閒詁, ed. Sun Yiran 孫詒讓 (Taipei: Shijie, 1962), 7.27: 182.

142. This is also the case of the personification of life span as a deity, Siming, the Manager of Allotments. As a subjective and intentional entity, Siming displays capacity to comprehend and respond to human queries, as well as to act through its own power.

143. See Edward Heath Robinson, "A Theory of Social Agentivity and its Integration into the Descriptive Ontology for Linguistic and Cognitive Engineering," International Journal on Semantic Web and Information Systems 7.4 (2011), 62-86. Some scholars have already suggested something similar. Chen Daqi 陳大齊, referring to the Mengzi's observation that "what is done without no one doing it, is due to Heaven" (莫之為而 為者, 天也), interprets that Heaven acts through human agency. See Chen, Mengzi dai jie $l u$ 孟子待解錄 (Taipei: Taiwan shangwu, 1981), 94-96. See the discussion in Shun, Mencius and Early Chinese Thought, 77. 
portrayed as making use of human agents to achieve its goals (note that the word "agent" in English also has the meaning of "acting on behalf of another").

The following anecdote provides an example of Heaven's social agentivity:

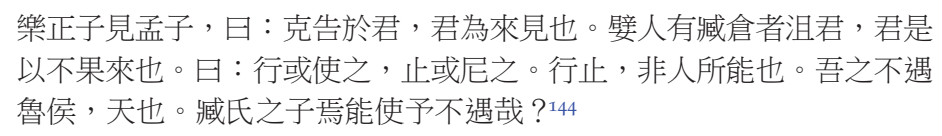

Yue Zheng saw Mencius and said to him: "I told the prince about you, and he was going to come and meet with you. However, among his favorites there is a Zang Cang, who stopped him, and consequently the prince will not come, although that was originally his purpose." Mencius said: "If [I were supposed to] advance, there would have been someone to favor it (the prince's meeting). If [I were supposed] not to advance, there would be someone to impede it (the prince's meeting). To advance or not to advance is beyond human power. My not encountering the prince of $\mathrm{Lu}$ is because of Heaven. How could that son of the Zang family cause me not to encounter (an opportunity)?"

Mencius' failure to encounter the right opportunity to advance in his career, the meeting with the prince of Lu, even though seemingly provoked by a persuasive Zang Cang who would have spoken to the prince against Mencius, must be understood as the workings of Heaven through a human representative. Zang Cang, or any other person for that matter, Mencius explains, has no power to prevent the rise and fall of opportunities. Only Heaven has the capacity to do so, yet Heaven acts through human agents in whom therefore the responsibility and causation of outcomes is erroneously placed.

Finally, as a third theory of Heavenly action we find the wuwei 無 為 theory. Some texts describe the actions of Heaven as "non-action," namely non-goal oriented, spontaneous and, importantly, non-intentional. This is the case in texts that share a worldview in which Heaven should not be anthropomorphized, but should rather be understood as a natural element. The Lun heng offers a well-known refutation of the purported subjective qualities of intentionality and purposiveness of Heaven, and explains that the actions of Heaven happen in a natural, spontaneous way. In particular, the "Ziran" 自然 chapter responds to common arguments, such as those of the Mozi, which claim that Heaven produces goods and means of sustenance for the benefit of

144. Mengzi zhushu 2B.48a. 
humans (或說以為天生五穀以食人), ${ }^{145}$ or that Heaven has intentions, as movement must be preceded by desire (有欲故動). ${ }^{146}$ In opposition to these views, the chapter argues that the movement of Heaven is unintentional ( $b u$ yu 不欲) and spontaneous (ziran 自然). Much as the dao 道 is repeatedly portrayed to act in early texts, the Heaven of the Lun heng acts in a wuwei manner.

But what about ming-fate? Could it possibly also act through non-action? To my knowledge, there are no accounts that relate ming and wuwei in early China. Does fate act directly, then, or perhaps through human agents? When fate is made responsible for a premature death, is it acting directly to end the appointed person's life? Or, when fate is made responsible for someone's distress and misfortune, is it acting through human agents, which we could call key actors, who would function as fate's puppets to bring a particular situation about? Although we may want to hypothesize that this might be the case, the truth is that our early accounts are far from clear in this respect.

Early texts do not construe a clear relationship between fate, as an agent, and its actions. They are not concerned with how fate acts, or, for that matter, with the theory of action behind fate's agency. What they are concerned about, and what they tirelessly emphasize, is the fact that fate does act and that its actions are widely felt, despite human inability to understand how it happens. Fate affects all external spheres of life, yet it remains unknowable:

\section{仲尼曰：死生存亡, 窮達貧富, 賢與不肖, 毀譽、耭渴、寒暑, 是事之 變，命之行也；日夜相代乎前，而知不能規乎其始者也。147}

Zhongni said: "Death and life, preservation and loss, failure and success, poverty and wealth, worthiness and unworthiness, slander and praise, hunger and thirst, cold and heat; these are the transformations of circumstances, the operations of fate. Day and night, they replace each other before us, yet our understanding has not capacity to discover their origination."

The operations of fate (命之行) are felt worldwide, yet their origination remains in the dark for human knowledge. As I have previously noted, according to early Chinese accounts of fate's agency, the way in which fate acts is mysterious, which makes it difficult if not impossible to understand the theory of action that lies behind. As a consequence

145. Lun heng jiaoshi $54 \cdot 775$.

146. Lun heng jiaoshi 54.776 .

147. Zhuangzi jijie 5.52. 
of the process of reification, fate became an unknowable and opaque object towards which human knowledge stayed powerless. The qualification of unknowability, to be often seen in early texts, seems to go even further. Not only it is true that the ways in which fate exercises its influence on human life are unknowable, but even more so that, when humans search for a causing agency, and they fail to find out why and how something happened, then they attribute it to fate.

An anecdote in the Zhuangzi provides a clear illustration of this train of thought. This is the way in which Zisang explains how he reached the conclusion that his situation of extreme poverty could only be caused by fate:

曰：吾思乎使我至此極者而弗得也。父母豈欲吾貧哉？天無私覆，地 無私載, 天地豈私貧我哉? 求其為之者而不得也。然而至此極者, 命 也夫! ${ }^{148}$

[Zisang] said: "I was thinking about what may have caused me to reach such an extreme situation, and I could not reach a conclusion. How would my parents have wished me to be so poor? Heaven covers all without partiality, and Earth sustains all without partiality; how would have Heaven and Earth made me so poor with such a partiality? I was trying to find out what had done it, and I could not do so. But here I am in this extreme situation: it is no other than fate!"

A second way in which humans recognize the agency of fate, as opposed to other causal agencies, is when they attempt by all means to reach a particular outcome or to attain a certain goal, yet they fail. Then they find as explanation that there is a major force working against their efforts, which they call fate:

孔子遊於匡, 宋人圍之數匝, 而絃歌不怓。子路入見, 曰：何夫子之娛 也? 孔子曰：來吾語女。我諱窎久矣, 而不免, 命也. ${ }^{149}$

When Confucius was travelling in Kuang, some people of Song surrounded him several ranks deep, but he kept singing to his lute without being troubled by it. Entering, Zilu saw him and said: "How is it, Master, that you are so amused?" Confucius replied: "Come here, and I will tell you. I have been trying to avoid such a strait for a long time, and the fact that I have not been able to escape it shows that it is due to fate."

148. Zhuangzi jijie 6.69.

149. Zhuangzi jijie 17.145. 
These two ways of identifying fate as the agent behind inexplicable and inevitable outcomes remind us of the two definitions of ming with which we began the discussion. First, from the point of view of the causing agency, we saw that ming was what happens with no one causing it. Namely, what happens not as a consequence of human effort, and with unknown cause and means of execution. Just like Zisang observes in the passage above, when an outcome is inexplicable and we cannot ascribe its agency to any other potential agent, the outcome must be attributed to fate. Second, from the point of view of its repercussion in humans, we saw that ming was what remained beyond our control, the inevitable. Much as Confucius observes in the passage above, when we put our efforts in achieving a particular goal yet we do not succeed, it shows that the outcome is inevitable and it must be due to fate. The way in which fate acts is described as inexplicable and inevitable, unknowable and inviolable. Which leads us to the conclusion that the theory of action behind fate's agency in early Chinese philosophy is no other than a theory of inexplicability and inevitability. ${ }^{150}$

This discussion helps us pinpoint which might be the central feature of fate in early China: fate's unknowability, accompanied by its inevitability, makes it the most uncertain of agencies, the one that produces the deepest sense of helplessness in humans. At the core of the human experience of fate we find mystery, uncertainty, and helplessness. Much as any other agent, human or non-human, fate displays its own form of autonomy. No autonomous agent can be fully controlled, and therefore the interaction with autonomous agents generates contingency and uncertainty. This is very clear in the early Chinese military literature. The commander can never fully predict how the enemy will behave, at the same time that the enemy can never fully predict how the other commander and his army will behave. This deadlock entails the issue of "double contingency." 151 The commander applies all sorts of strategies and techniques to predict and manipulate the enemy's behavior, but the enemy's response is ultimately out of the commander's control.

150. In his article in defense of fatalism, Solomon explained that "Fate and fatalism can exist without acknowledging any agency. The emphasis is on the narrative where outcomes are doomed necessary, and not in the agency producing them." See Robert C. Solomon, "On Fate and Fatalism," 442. His study does not concern Chinese views of fate and fatalism. Speaking specifically for the early Chinese case, I agree with his general claim in that narratives privilege the necessary character of outcomes over the means or the agency that make these outcomes happen. However, in early China fate is thought of as an agent, even though an agent whose theory of action remains unknowable.

151. The term "double contingency" was first coined by Talcott Parsons, The Social System (New York: Free Press, 1951). 
However, as contingent as the interaction between two intentional agents might be, in dealing with another subjectivity, as we have seen, there are many possible transactions. There are possibilities of communication, interpretation, persuasion, prediction, anticipation, even manipulation.

There are no such possible transactions in the face of autonomous, non-subjective agency such as a reified, opaque fate. The fact that the motives or intentions behind fate's actions can never be known (probably because it is a non-intentional form of agency), combined with the fact that the outcomes of fate's agency are ultimately inviolable and inevitable, makes of fate, in the mind of early Chinese thinkers, the single most overwhelming kind of agency that there is.

The blows of fate made people feel helpless. In Greek, the sense of helplessness and want of means was expressed in the term amechania, literally the lack of mechané, the cunning or device humans can use to get out of a situation of existential difficulty. ${ }^{152}$ As philosopher and cultural critic Sloterdijk remarks, by lacking mechané "human beings are denied just what the Greeks believed made them wholly human, that is, the ability to retaliate against attacks, being equipped with options for action or, as we would say today, being in full control of their agency."153 In other words, amechanía is the situation in which the person is deprived of the most basic sense of existential competence. If we call competence the possession of the skills, knowledge, or capacity required to perform effectively in a situation (usually a job in today's language), existential competence is the possession of skills, the mechané, to act effectively in life. In the face of fate, early Chinese thinkers felt an inextricable lack of existential competence. The non-subjective agency of a reified fate hit humans out. It left them feeling powerless and humbled. The process of reification made of fate an agent which could not be interpreted, tackled, or faced, but which could only be awaited and accepted in the best terms possible.

In order to recover existential competence, some new mechané must be created. Early Chinese thinkers designed a variety of philosophical strategies to cope with uncertainty and unpredictability in ordinary life, and to recover control and existential competence in the face of the vagaries of fate and other phenomena beyond human power. They produced a series of competing responses to these issues, many of which remain relevant today. ${ }^{154}$

152. Sloterdijk, Selected Exaggerations, 266.

153. Sloterdijk, Selected Exaggerations, 266-67.

154. I have discussed some of these strategies in Valmisa, "Beyond our Control?" and at length in "Changing Along with the World: Adaptive Agency in Early China," Ph.D. dissertation (Princeton University, 2017), ch. 4, 253-328. 
論早期中國「命 」之物化

梅麗

提要

早期中國文本裡有很多關於人類是否對事件的進程、其行動的結果以 及他們自己的生活具有影響力的争論。在關於人類能動性功效的爭論 中, 命的概念佔據了中心位置。

在這篇文章中, 我提出了一個早期中國關於人類與世界關係的思維範 式。我稱其為物化模式, 因為它將命視為具類似物體特徵的實體。雖然 命是外在和獨立的, 但它並不被賦予人性的品質, 例如同理心、反應能 力和主體間性。命的物化暗示了把命理解为一種外在的、非德的、決定 性的力量。這種力量限制了人類而不接受與人類的互動交流, 從而導致 異化、無力和存在無能的感覺。

我首先表明, 命的不同含義皆有佔優勢的外在現實感, 因此可以與 命運（fate）總體意義建立關聯。然後, 我通過《孟子》與《唐虞之 道》文本的案例研究, 提供了早期中國命運的物化過程及其理論與實 踐的後果。最後, 我提供一些反思, 闡明命作為一個非個人和非主體 性的能動者對早期中國和廿一世紀的能動性理論有何種影響。

Keywords: $\operatorname{ming}$ 命, fate, agency, nonpersonal agent, reification 命, 命運, 能動性, 非個人能動者, 物化 